\title{
Age and Growth of the Striped Searobin
}

John D. McEachran

College of William and Mary - Virginia Institute of Marine Science

Follow this and additional works at: https://scholarworks.wm.edu/etd

Part of the Fresh Water Studies Commons, Marine Biology Commons, Oceanography Commons, and the Zoology Commons

\section{Recommended Citation}

McEachran, John D., "Age and Growth of the Striped Searobin" (1968). Dissertations, Theses, and Masters Projects. Paper 1539617406.

https://dx.doi.org/doi:10.25773/v5-nw3t-7z46

This Thesis is brought to you for free and open access by the Theses, Dissertations, \& Master Projects at W\&M ScholarWorks. It has been accepted for inclusion in Dissertations, Theses, and Masters Projects by an authorized administrator of W\&M ScholarWorks. For more information, please contact scholarworks@wm.edu. 
AGE AND GROWTH OF THE STRIPED SEAROBIN

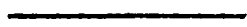

A Thesis

Presented to

The Faculty of the School of Marine Science

The College of William and Mary in Virginia

In Partial Fulfillment

Of the Requirements for the Degree of

Master of Arts

By

John D. McEachran

1968 


\section{APPROVAL SHEET}

This thesis is submitted in partial fulfillment of the requirements for the degree of

Master of Arts

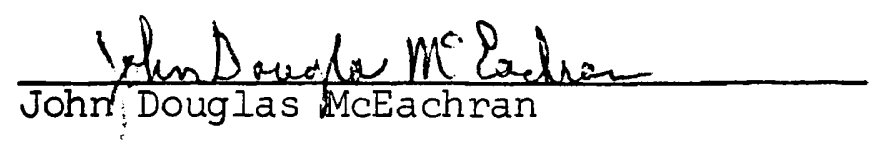

Approved, August 1968

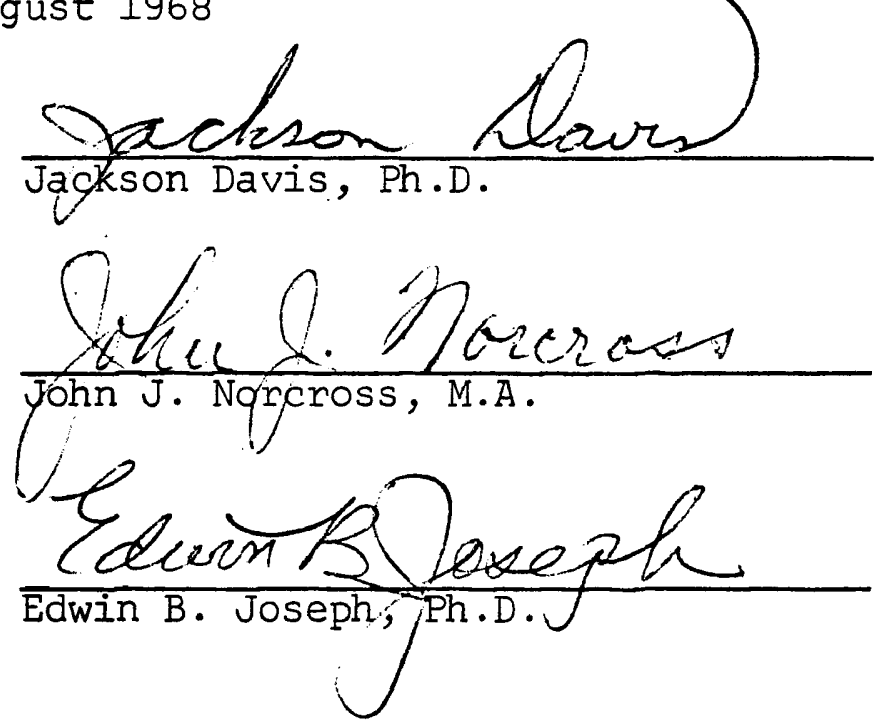




\section{ACKNOWLEDGMENTS}

The author wishes to express his appreciation to Associate Professor Jackson Davis for his guidance during this study and for his criticism of the manuscript. Thanks are also given to Associate Professor John J. Norcross and Professor Edwin B. Joseph for their counsel and their criticism of the manuscript. Dr. John A. Musick gave valuable help in the statistical analyses.

Mr. Peter J. Eldridge, Mr. James S. Sterling and Captain Wilton E. Mansfield, of the SEA BREEZE, gave valuable assistance in collecting specimens during the survey.

Thanks are expressed to those who gave technical assistance. Mr. William Allen helped to develop the technique for processing the otoliths. Mrs. Jane Davis and Miss Kay Brown drew the illustrations. Mr. Fred Biggs and Mrs. Linda Sweat photographed the otoliths. Mrs. Alice Lee Tillage and Mrs. Beverly Schieler typed the manuscript.

This study was a part of Project 3-5-D, a joint program of the Bureau of Commercial Fisheries and the Virginia Institute of Marine Science under provision of the Commercial Fisheries Research and Development Act of 1965 (PL 88-309). 
TABLE OF CONTENTS

Page

ACKNOWLEDGMENTS $\ldots \ldots \ldots \ldots \ldots \ldots \ldots \ldots \ldots \ldots \ldots \ldots \ldots \ldots \ldots \ldots \ldots \ldots \ldots \ldots$

LIST OF TABLES............................... $v$

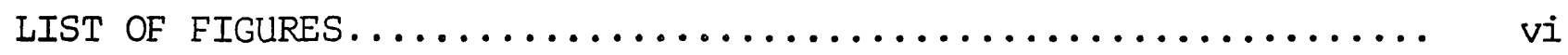

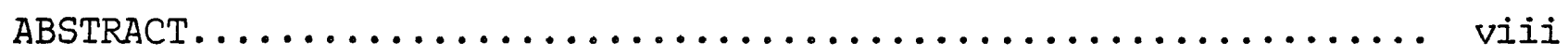

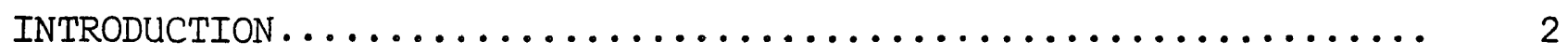

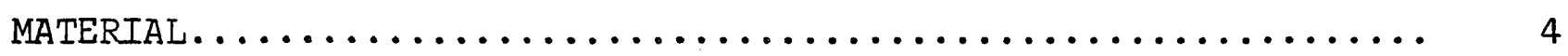

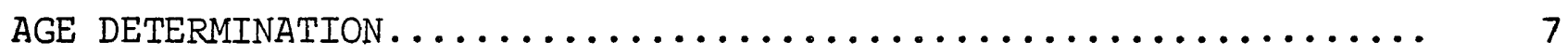

HARD PART ANALYSIS, CRITIQUE OF THE METHOD.............. 7

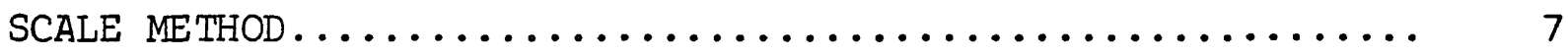

OPERCULAR METHOD............................... 8

OTOLITH METHOD................................ 8

LENGTH FREQUENCY METHOD........................ 23

COMPARISON OF THIS STUDY WITH AN EARLIER STUDY.......... 28

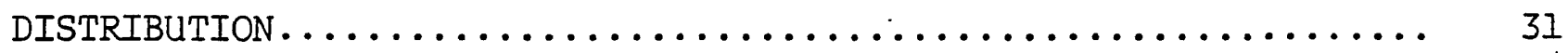

GONAD DEVELOPMENT, MATURITY AND SPAWNING............... 36

WEIGHT/LENGTH RELATIONSHIP....................... 38

RELATIVE CONDITION................................. 4 I

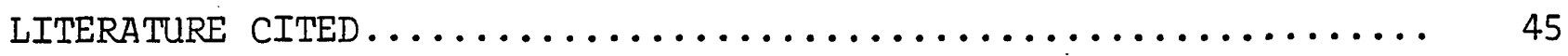




\section{LIST OF TABLES}

Table

Page

1. Dates of collection of striped searobins............ 5

2. Bottom water temperatures at sample sites............ 15

3. Mean lengths of yearlings as determined by length

frequency method and by the otolith method..... 27

4. Number and fork lengths of striped searobins obtained

from inlets and estuaries during 1966-67...... 29

5. Lengths of age groups 0-III obtained by this study and those obtained by Marshall's study........... 30

6. Results of covariance tests run between seasonal samples.. 39 
LIST OF FIGURES AND PLATES

Figure

Page

1. Saccular otolith of the striped searobin........... 10

2. Seasonal change in the margin of the otolith of the striped searobin.................. 13

3. Relationship of dorsal radius of the otolith to fork

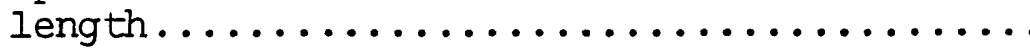

4. Mean lengths and confidence interval of the means of age groups of striped searobins prior to growth in 1966 and $1967 \ldots \ldots \ldots \ldots \ldots \ldots$

5. Mean lengths and confidence interval of the means for age groups of striped searobins during each

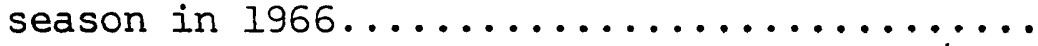

6. Length frequencies of the striped searobins during each of the seasons of $1966 \ldots \ldots \ldots \ldots \ldots \ldots \ldots \ldots$

7. Length frequencies of the striped searobins during the first three seasons of $1967 \ldots \ldots \ldots \ldots \ldots \ldots$

8. Distribution of striped searobins in Chesapeake Bight during winter, 1966. Distribution of striped searobins according to depth and bottom water temperature during winter, 1966..........

9. Distribution of striped searobins in Chesapeake Bight during spring 1966. Distribution of striped searobins according to depth and bottom water temperature during spring,1966.

10. Distribution of striped searobins in Chesapeake Bight during summer, 1966. Distribution of striped searobins according to depth and bottom water temperature during summer, $1966 \ldots . .$.

11. Distribution of striped searobins in Chesapeake Bight during autumn, 1966. Distribution of striped searobins according to depth and bottom water temperature during autumn, $1966 . . .$. . 
Figure Page

12. Weight/length relationship for striped searobins in pre spawning and in post spawning condition........................ 42

13. Relative condition (Kn) for striped searobins in pre spawning condition............... 44

Plate

Page

I. Seasonal change in the margin of the otolith of the striped searobin................ 14

II. Irregularities in growth of the otolith of the striped

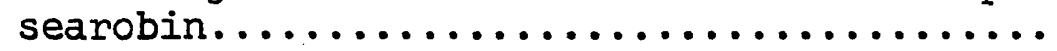




\section{ABSTRACT}

Age, growth, relative condition, and distribution of the striped searobin were studied. The fish were collected from Chesapeake Bight and Chesapeake Bay during 1966 and 1967. The age of 803 fish was determined from otoliths. The otoliths were cross-sectioned and the exposed surface was then polished and heated. Age groups 0 to VII were represented in the sample. Males and females had the same growth rate and weight/length relationship. Growth in length was rapid until the fish reached maturity at age II. Age group II averaged $221 \mathrm{~mm}$ fork length. The fish accomplished most annual growth between May and September. Spawning occurred from May through July. Relative condition was plotted against fork length. The high values of relative condition corresponded to the mean lengths of age groups II, III, and V prior to the spawning season. Relative condition was thus an indicator of the length at sexual maturity and length at each succeeding year. The fish annually moved offshore in autumn and onshore in spring. 
AGE AND GROWTH OF THE STRIPED SEAROBIN 


\section{INTRODUCTION}

The purpose of this study was to develop a method for determining the age of the striped searobin Prionotus evolans. (Linnaeus, 1766) and to reveal certain aspects of its biology such as: the rate of growth, age at sexual maturity, weight/ length relationship, and seasonal distribution. Specimens were taken from Chesapeake Bight and Chesapeake Bay during 1966 and 1967.

Formerly Prionotus evolans was split into two species (Jordan and Hughes, 1887). Fish from the northern part of the range, the continental shelf from Cape Cod to Virginia, were classified as Prionotus strigatus (Cuvier and Valenciennes, 1829); those from the southern part of the range, off North and South Carolina, were designated as Prionotus evolans. The distinction was based on slight morphological and color differences. The southern species had relatively longer pectoral fins, which were plain rather than checkered as in the northern species. Jordan and Evermann (1898) preserved the specific distinction although they recognized that the two species might be geographical races. A comparative study was not undertaken until Ginsburg (1950) reviewed the systematics of the Triglidae of the Western Atlantic. Concluding that the differences cited by Jordan and Hughes (1887) were not sufficient to separate the populations at the subspecific level, he placed both forms in the same species, Prionotus evolans. 
The striped searobin is a benthic fish which occurs on the continental shelf from Cape Cod to South Carolina (Bigelow and Schroeder, 1953) with a few strays reported outside of this range. In 1957 three fish were captured in the lower Bay of Fundy (Leim and Day, 1959) and between 1957 and 1960 specimens were taken from the northeastern coast of Florida (Bullis and Thompson, 1965).

Sumner, et al., (1913) stated that this species is parasitized by the acanthocephalan, Echinorhyncus acus, the cestodes Rhynchobothrium imparespini and Tetrarhynchus bisulcatus; and the trematodes, Distomum spp.

According to Nichols and Breder (1927), striped searobins feed primarily on crustaceans and mollusks. Hildebrand and Schroeder (1928) examined the stomachs from five fish and found the contents to consist entirely of small crustaceans, mostly mysids. Marshall (1946) stated that the majority of the food items are crustaceans found within a foot of the bottom. He discovered Neomysis americana, Gammarus Iocusta, and Crangon septemspinosus to be the most abundant food items.

Fish (1954) reported that striped searobins make sounds by contracting the striated muscles embedded in the outer surface of each lobe of the swim bladder. The muscular contraction sets up audible vibrations within the swim bladder. Fish. described the sound as a series of grunts or clucks. Moulton (1958) stimulated sound production of this fish by transmitting sounds of the same. frequency to it during spawning season. 


\section{MATERIAL}

From 1966 through 1967, 1600 striped searobins were obtained from the continental shelf, inlets and estuaries in 9 sampling periods (Table 1). The bulk of the specimens came from the continental shelf between Cape May, New Jersey, and Cape Hatteras, North Carolina, at depths of 5 to 100 fathoms. All but the April, 1966 sample were collected from the trawler SEA BREEZE, under charter by the Virginia Institute of Marine Science. The SEA BREEZE was equipped with a semi-balloon trawl possessing an inner liner of $1 / 2$ inch stretch mesh in 1966 and in July, 1967, and an Atlantic western trawl with a two inch stretch mesh cod end in the remainder of 1967. The April, 1966 sample was captured by a trawler of the Hampton, Virginia, fleet using a Yankee trawl with a 4 inch stretch mesh cod end.

The estuarine samples, taken from Chesapeake Bay, comprised only $4 \%$ of the collection. They were obtained in spring and sumer and included single pound net samples obtained from the James River in April, 1966 and May, 1967 from the York River and samples from a trawl with a cod end of 3/4 inch stretch mesh.

The inlet samples, representing less than $0.4 \%$ of the collection, were taken in the seaside inlets of Eastern Shore, Virginia, during the spring and summer sampling periods. The samples were collected with a trawl possessing a 3/4 inch stretch mesh codend. 
TABLE I

DATES OF COLLECTION OF STRIPED SEAROBINS

\begin{tabular}{|c|c|c|c|}
\hline Sampling Period & Date & Number Analyzed & Total \\
\hline Winter & Feb.-March 1966 & 61 & 66 \\
\hline Spring & April 1966 & 62 & 84 \\
\hline Spring & May 1966 & 198 & 224 \\
\hline Summer & Aug.-Sept. 1966 & 146 & 215 \\
\hline Autumn & Nov.-Dec. 1966 & 144 & 144 \\
\hline Winter & March 1967 & 56 & 445 \\
\hline Spring & May 1967 & 84 & 275 \\
\hline Summer & June 1967 & 15 & 41 \\
\hline Summer & July 1967 & 37 & 106 \\
\hline Total & & 803 & 1,600 \\
\hline
\end{tabular}


Hydrographic data were collected from the SEA BREEZE during all of her sampling trips. Prior to setting the trawl, bottom temperature and a salinity sample were obtained with a bathythermograph and a Kemmerer bottle. Water depths were recorded with a Kelvin-Hughes white line fathometer.

Fish were weighed in grams and measured to the nearest millimeter of fork length. The gonads were inspected macroscopically to determine sex and stage of development. The fish were classified as: immature, gravid, running ripe, or spent, depending on the state of the gonads. A subsample of 803 fish representing all of the sampling periods was used for age determination by analysis of hard parts (Table 1). In 1966, scales, opercula, and otoliths were removed from the selected fish. In 1967 only otoliths were collected. 


\section{AGE DETERMINATION}

Hard Part Analysis, Critique of the Method

Age determination by analysis of hard parts (scales, opercula, or otoliths) is based on the premise that growth slows or stops during part of the year and that the change in growth rate is marked on the hard parts. For a hard part to be reliable for determining age, it must not only have annual rings, but the rings must be formed at approximately the same time every year (Van Oosten, 1929). Also, growth of the hard part should be proportional to the growth of the fish. Fulfillment of these requirements insures that the annuli will be regularly spaced and thus aids in distinguishing annual rings from false annuli which may form during the growing season.

Annual rings could be determined with confidence on the otoliths but not on the opercula or scales.

Scale Method

About 20 scales were removed from the left side of the body below the second dorsal fin and between the lateral line and the lower lateral stripe. These scales were symmetrical and of uniform size. The scales were soaked in water for 12 hours, dried with xylene, and mounted in a vertical row on a glass slide. Each slide contained five vertical rows of scales, each row having four scales and representing a separate fish. The mounting medium was prepared by mixing equal portions of euparol 
and euparol essence. A second slide was placed over the scales and the two slides were bound together at each end with tape. The scales were examined with both a dissecting microscope and an Eberbach micro-projector. Several features of sculpturing on the scales made identification of annuli uncertain: the circuli were set close together, the "cutting over" of internal circuli by adjacent external circuli occurred randomly in the lateral fields of the scale, circuli anastomosed randomly, and secondary radii were not formed according to any fixed pattern. Previous authors have used approximation of circuli, "cutting over" of circuli, anastomosing of circuli, and origins of secondary radii to indicate annuli on ctenoid scales (Tester, 1932; Creaser, 1926; Marshall, 1946; and Taylor, 1914). The disorderly arrangement of these features on the scales used in this study precluded the use of scales for age determination.

Opercular Method

The left opercular bone was removed. with a scalpel and stored in an envelope. The operculum was cleaned by placing it in boiling water and removing the adherent tissue with a tooth brush. However, the opercula were of little value in age determination because they became opaque with increase in size. Although rings could be discerned near the nucleus on opercula of small fish, rings were evident only near the margin on opercula of large fish. The opercula thickened as they grew and thickening apparently obscured annuli on opercula of large fish. Otolith Method

The left, or both, saccular otoliths were exposed with a scalpel and removed with forceps. The otoliths were stored in 
vials containing corn syrup and several drops of phenol. The corn syrup prevented desiccation, a requisite for age determination because dried otoliths were uniformly opaque. Phenol prevented fungal growth.

The saccular otolith, in lateral profile, is an oblong rugose concretion (Fig. 1). The anterior end is rounded. The posterior end is rounded ventrally but the dorsal section is slightly indented. The ventral edge is smooth and moderately curved while the dorsal edge is irregular and more strongly curved. Viewed dorsally, the otolith appears laterally compressed and slightly crescent shaped. The medial surface is convex and the lateral surface is concave. A groove, the sulcus acousticus, runs anteroposteriorly along the medial surface.

The dorsal and anterior radii were measured before the otoliths were prepared for age determination. The otoliths were placed in a watch glass, concave surface up, covered with water, and examined with a dissecting microscope at $14 X$. Measurements, to the nearest ocular unit $(0.07 \mathrm{~mm})$, were made from the focus, a small opaque central area, to the dorsal and anterior margins (Fig. 1).

It was necessary to imbed the otoliths in plaster and then grind, polish, and heat them to distinguish the annuli. A heat resistant plaster called Vel Mix Stone was poured into cylindrical paper molds and slightly over one-half of the otolith was imbedded on a plane perpendicular to the long axis of the otolith. The station and specimen numbers were scratched on the base of the hardened plaster cylinder. A whetstone was used to grind the protruding section of the otolith flush with the 
Fig. 1

Saccular otolith of the striped searobin. Magnification $11 X$. 

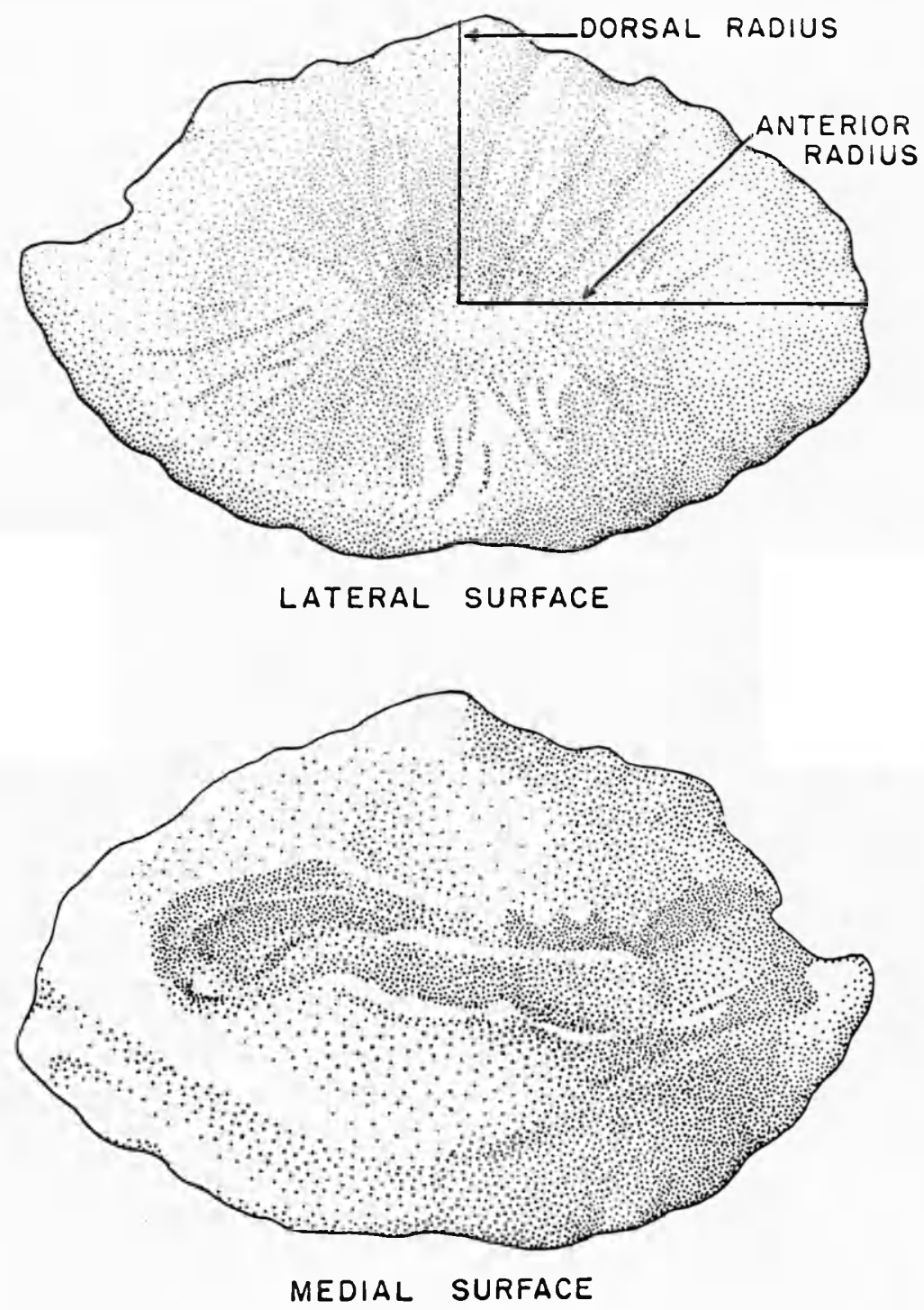
plaster. The otolith was further ground with \#320 alundum until the nucleus was exposed. This surface was then polished with finer abrasives, \#400 and \#600 alundum. The polished otoliths were heated in an electric furnace for 20 minutes, the time required for the furnace to reach 530 C. It has been demonstrated by Lawler and McRae (1961); Chugunova (1963); Christensen (1964); and Poinsard and Troadec (1966) that the visibility of annuli is enhanced by heating otoliths.

The heated otoliths had alternating dark and light bands. According to Hickling (1931), Irie (1955), and E. Dannevig (1956) the banding is due to a disproportion of organic and inorganic constituents. When growth is most pronounced, a greater percentage of inorganic salts is added; when growth is reduced, a greater percentage of protein is deposited (Irie, 1957). Annual growth consists of a wide crystalline band and a narrow protein band. The protein band customarily considered to be the annulus can be differentiated from the remainder of the otolith with heat. Heating oxidizes the protein and darkens it without affecting the crystalline ring.

The annulus formed in autumn remained on the margin of the otolith until the following spring (Fig. 2). This is the same phenomenon described for other species by A. Dannevig (1956), Bratberg (1956), Irie (1960), and Gambell and Messtorff (1964). About one-fourth of the yearlings captured in February and March had narrow crystalline bands outside the annulus (Plate I, Fig. A). The otoliths of older fish did not have crystalline edges until May (Plate I, Fig. B). The percentage of crystalline margins increased through July. Annulus formation began in August and 
the percentage of otoliths with protein bands increased through December. The otolith margins indicated that growth for most fish occurred between May and August.

The otolith margins showed growth commencing earlier for yearlings than for older fish. According to Nikolsky (1963) the reduced period of growth of older fish is due to the fact that metabolities in mature fish are used primarily for gonadal development and accumulation of fat for overwintering. The older striped searobins did not begin yearly growth until gonadal maturation was nearly complete. However, the two groups did not differ in time of termination of growth (Plate I, Figs. C and D). Thus the accumulation of fat did not affect the linear growth of the older fish more than that of the yearlings.

A majority of the fish began a new year's growth after commencement of vernal warming of the waters of the continental shelf. Table 2 lists the bottom water temperatures at sites where striped searobins were captured. Vernal warming began prior to May, the time at which crystalline material first appeared on the margins of most of the otoliths. However, growth terminated before there was a decline in water temperature. This phenomenon was also reported to occur in Coregonus clupeaformis (Van Oosten, 1923). A. Dannevig (1956) found that Gadus morhua formed an annulus even when held at a constant temperature. These observations suggest that, although temperature affects growth, other factors are involved. 
Fig. 2

Seasonal change in the margin of the otolith of the striped searobin. 


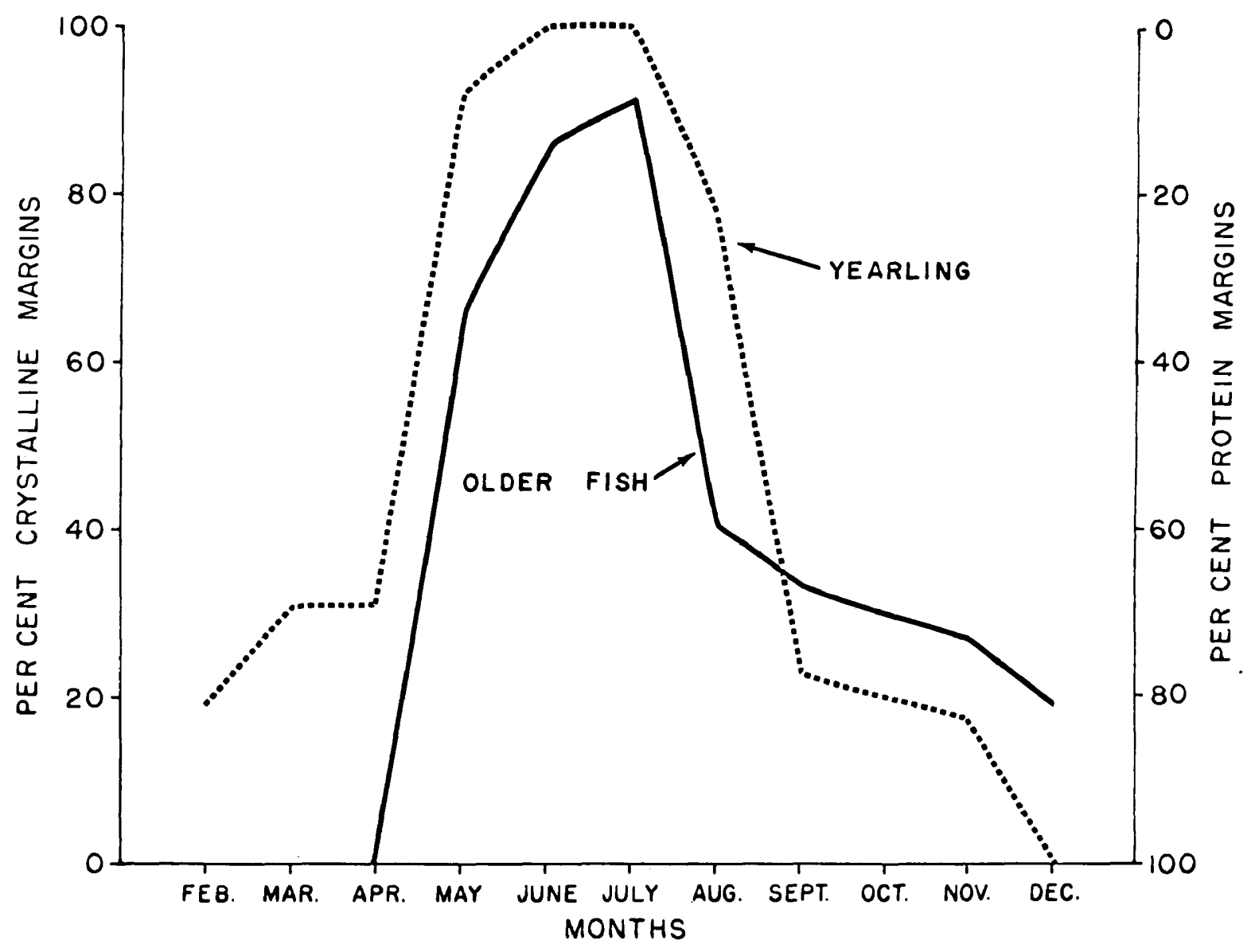




\section{Plate I}

Seasonal change in the margin of the otolith of the striped searobin.

Fig. A. A thin crystalline band on margin of an otolith from a yearling captured in March.

Fig. B. A thin crystalline band on margin of an otolith from a three year old fish captured in May.

Fig. C. A wide crystalline band on the margin of an otolith from a yearling captured in November.

Fig. D. A relatively wide crystalline band on the margin of an otolith from a four year old captured in November. 


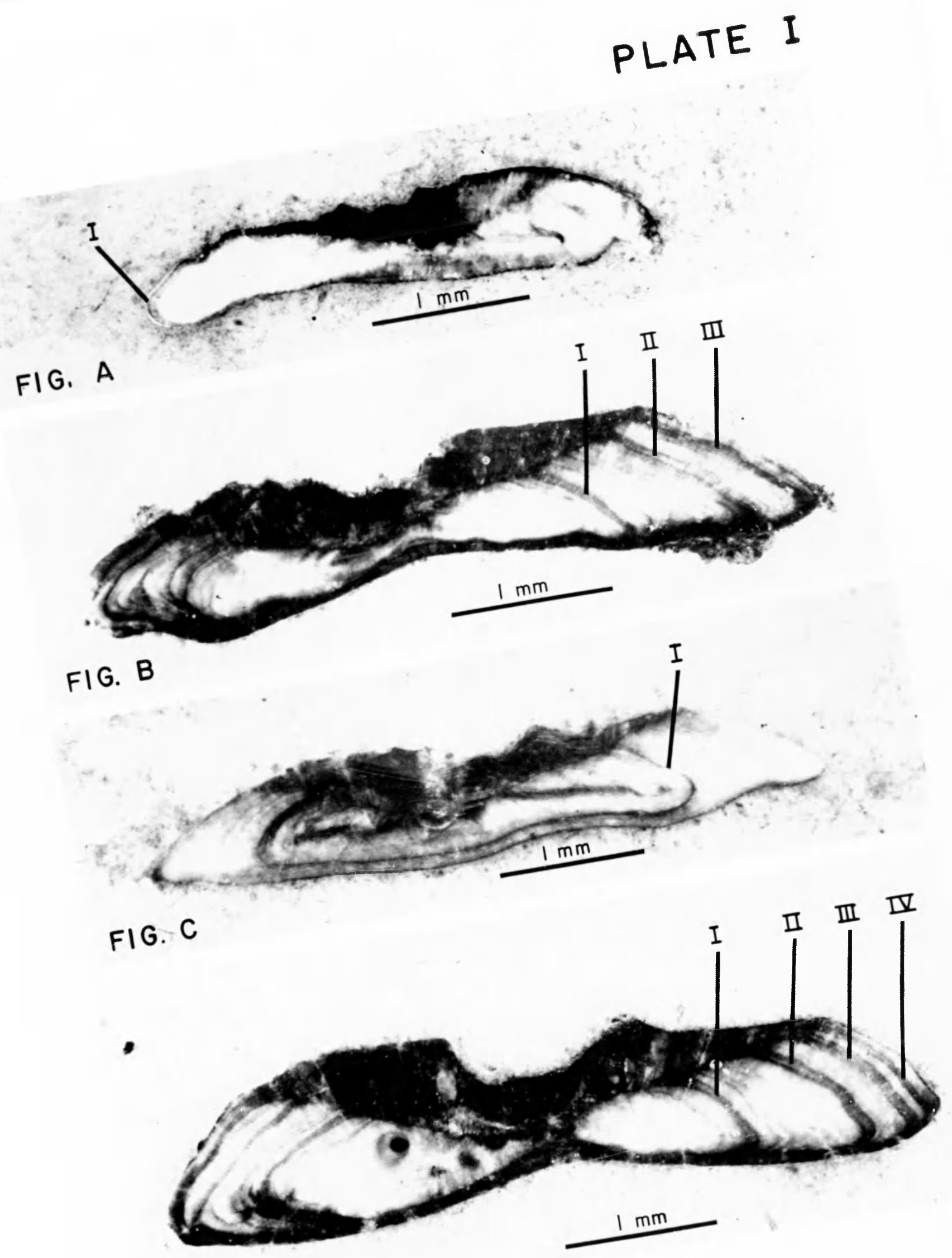

FIG. D 
TABLE 2

BOTTOM WATER TEMPERATURES AT SAMPLE SITES

1966

Temperature Range C Average Temperature C

\begin{tabular}{|c|c|c|c|}
\hline Eebruary & 5.6 &. .8 .4 & 6.4 \\
\hline March & 5.6 & -11.7 & 7.7 \\
\hline May & 11.9 & -15.4 & 13.7 \\
\hline August & 11.0 & -17.0 & 14.1 \\
\hline September & 13.0 & -23.0 & 19.2 \\
\hline November & 11.7 & -15.6 & 13.7 \\
\hline \multirow[t]{3}{*}{ December } & \multicolumn{2}{|r|}{14.4} & 14.4 \\
\hline & \multicolumn{3}{|c|}{1967} \\
\hline & \multicolumn{2}{|c|}{ Temperature Range C } & Average Temperature \\
\hline March & \multicolumn{2}{|r|}{10.3} & 10.3 \\
\hline May & 9.4 & -10.0 & 9.7 \\
\hline June & 7.8 & -11.1 & 9.8 \\
\hline July & 12.2 & -15.0 & 13.6 \\
\hline
\end{tabular}


Although growth of the otolith, both dorsally and anteriorly, was proportional to linear growth of the fish, the former axis of growth showed a closer relationship to growth in length than the latter. The dorsal radius of the otolith increased in a linear manner with fork length until the fish reached $315 \mathrm{~mm}$. After the fish attained about $315 \mathrm{~mm}$ fork length the growth of the otolith appeared to slacken in relation to linear growth (Fig. 3). For this reason, one linear regression was developed for fish $\leq 315 \mathrm{~mm}$ and a second was developed for fish $>315 \mathrm{~mm}$. The regression of otolith radius $(y)$ on fork length $(x)$ for $f i s h \leq 315 \mathrm{~mm}$ was: $y=1.1976+0.1547 x$ with a correlation coefficient of 0.82711 . The regression for fish $>315 \mathrm{~mm}$ was: $y=24.3208+0.0855 x$ with a correlation coefficient of 0.56123 . The two correlation coefficients indicated that otolith growth was closely related to growth in length for fish $\leq 315 \mathrm{~mm}$, but not for fish $>315 \mathrm{~mm}$. The fact that growth of the otolith did not appear to be proportional to growth in length for fish $>315 \mathrm{~mm}$ did not greatly influence the age analysis because only $6.5 \%$ of the specimens exceeded $315 \mathrm{~mm}$.

The processed otoliths thus satisfied the requirements for age determination. Annuli were laid down at about the same time every year and growth of the otolith was proportional to growth of the fish.

The processed otoliths showed the nucleus closer to the ventral margin than to the dorsal margin (Plate I, Figs. A-D). Since annuli were crowded on the ventral radius but well separated on the dorsal radius, age was determined by counting the annuli along the dorsal radius. The age of most fish could be determined 
Fig. 3

Relationship of dorsal radius of the otolith to fork length. 


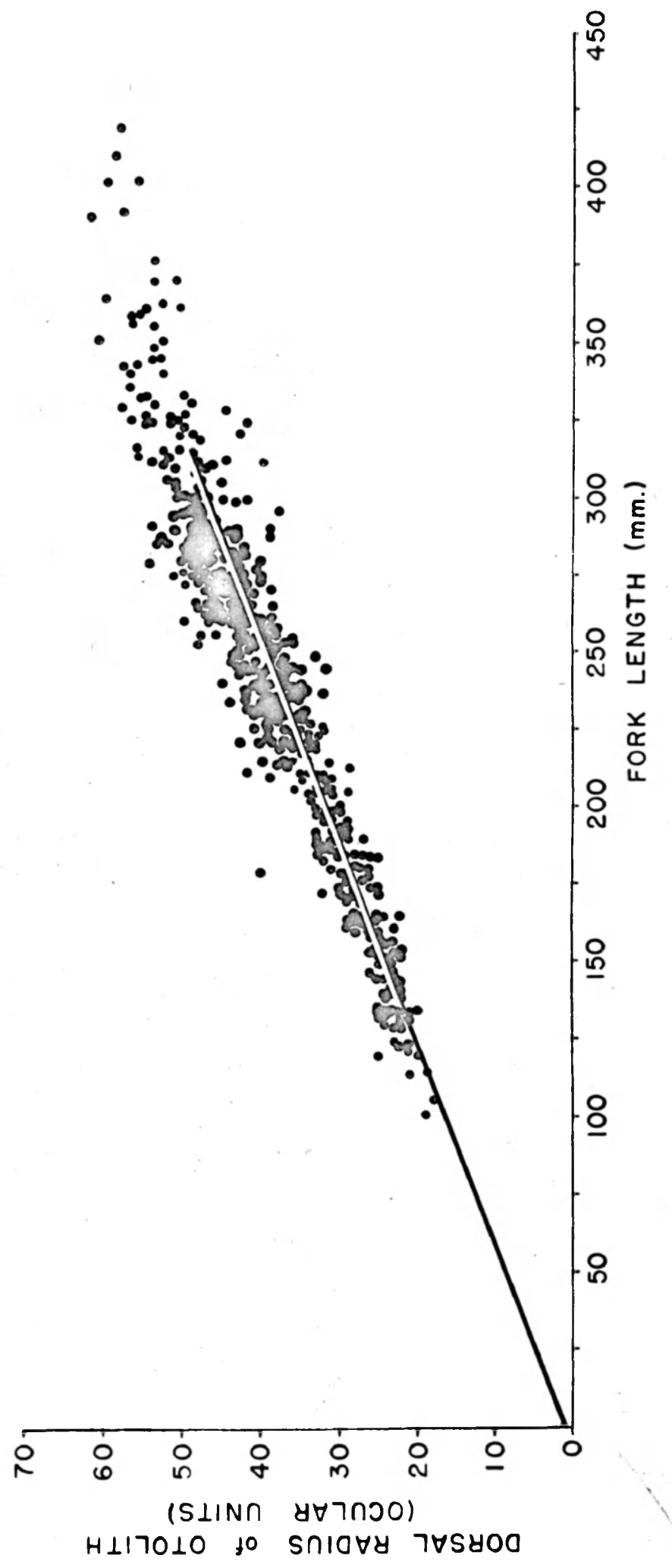


by this method; however, certain irregularities did occur.

Accessory rings were occasionally found between the first and second annuli (Plate II, Fig. A). These rings, of ten occurring in pairs, were judged to be accessory rings because they were thinner and less distinct than the two encompassing rings. Some of the otoliths formed double annuli (Plate II, Fig. B). Double rings could not be interpreted accurately when they occurred near the margins on otoliths of older fish because reduction of growth rate caused the rings to be set close together. Reorientation of growth on the dorsal margin was observed on some of the larger otoliths. Growth sometimes became more appreciable medial to the dorsal radius than along the dorsal radius after age IV or $V$ causing the annuli to be closely spaced and making age determination uncertain (Plate II, Fig. C).

The change in axis of growth may have been the reason why the relationship of dorsal radius of the otolith on fork length was uncertain for fish longer than 315. mm. Reorientation of growth on the dorsal radius may have been due to mechanical pressure of the otic capsule. Presumably the otolith continued to grow dorsally until interference from the otic capsule caused a reorientation.

Because of the irregularities in growth of the otolith and reduction of growth with time, age could be determined only up to seven years.

Figure 4 shows mean lengths in 1966 and 1967 prior to the new year's growth. Mean lengths of age group I were obtained from the samples collected during February and March, 1966 and March, 1967. Mean lengths of older age groups were obtained from the samples taken in May, 1966 and May, 1967. In 1966 the one and 


\section{Plate II}

Irregularities in growth of the otolith of the striped searobin.

Fig. A. Otolith from a seven year old fish.

1. False annuli.

Fig. B. Otolith from a seven or eight year old fish.

1. First double annulus.

2. Second double annulus.

3. Third double annulus.

Fig. C. Otolith from a seven year old fish.

1. Reorientation of growth after fourth year. 


\section{PLATE II}

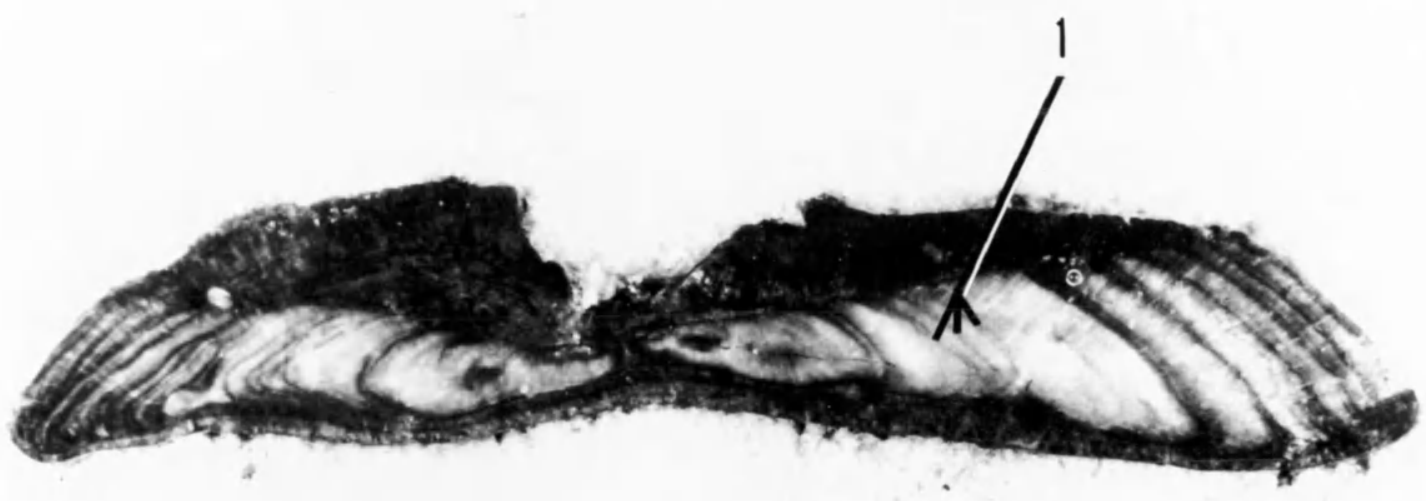

FIG. A

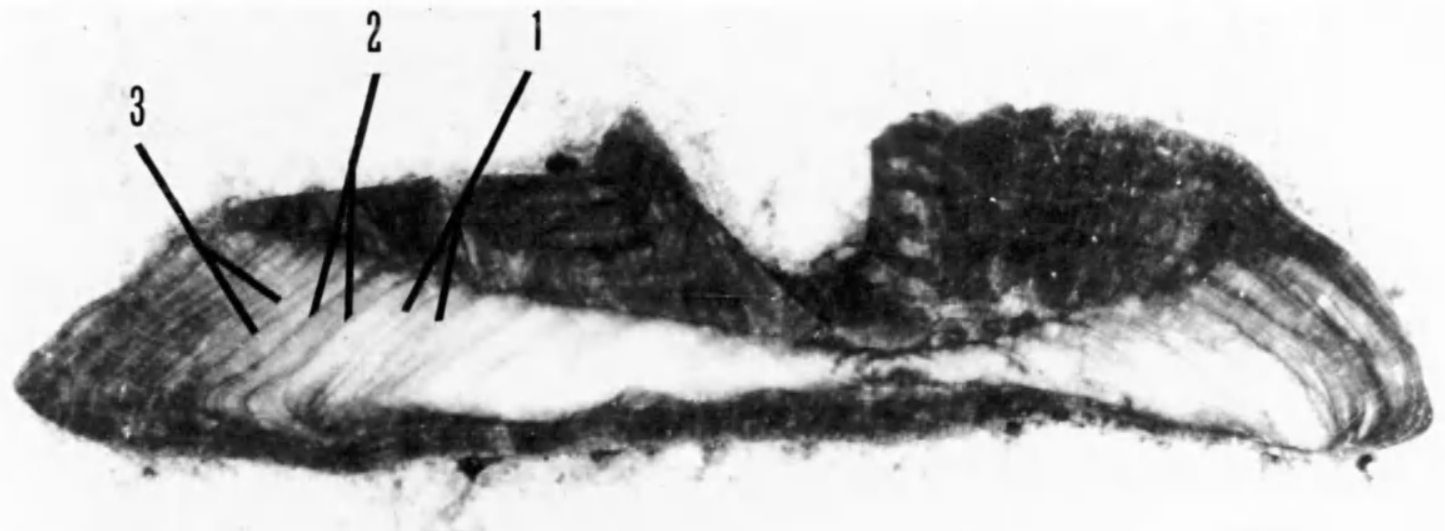

FIG. B

$1 \mathrm{~mm}$

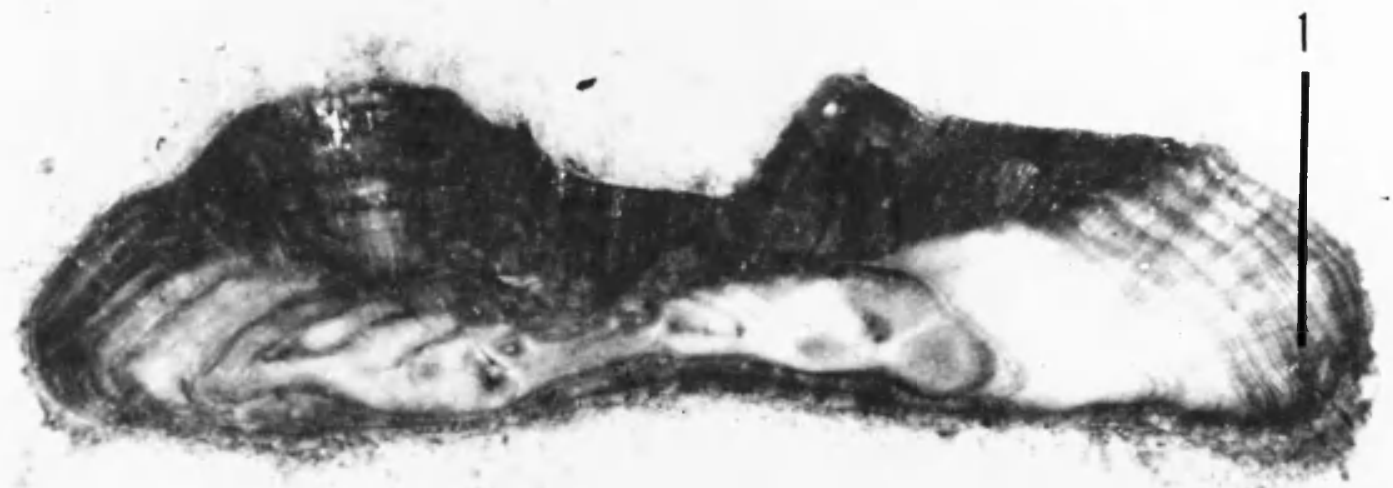

FIG. C 
Fig $\cdot 4$

Mean lengths and confidence interval of the means for age groups of striped searobins prior to growth in 1966.

Fig. 5

Mean lengths and confidence interval of the means for age groups of striped searobins during each season in 1966 . Numbers adjacent to the bars represent sample size. 

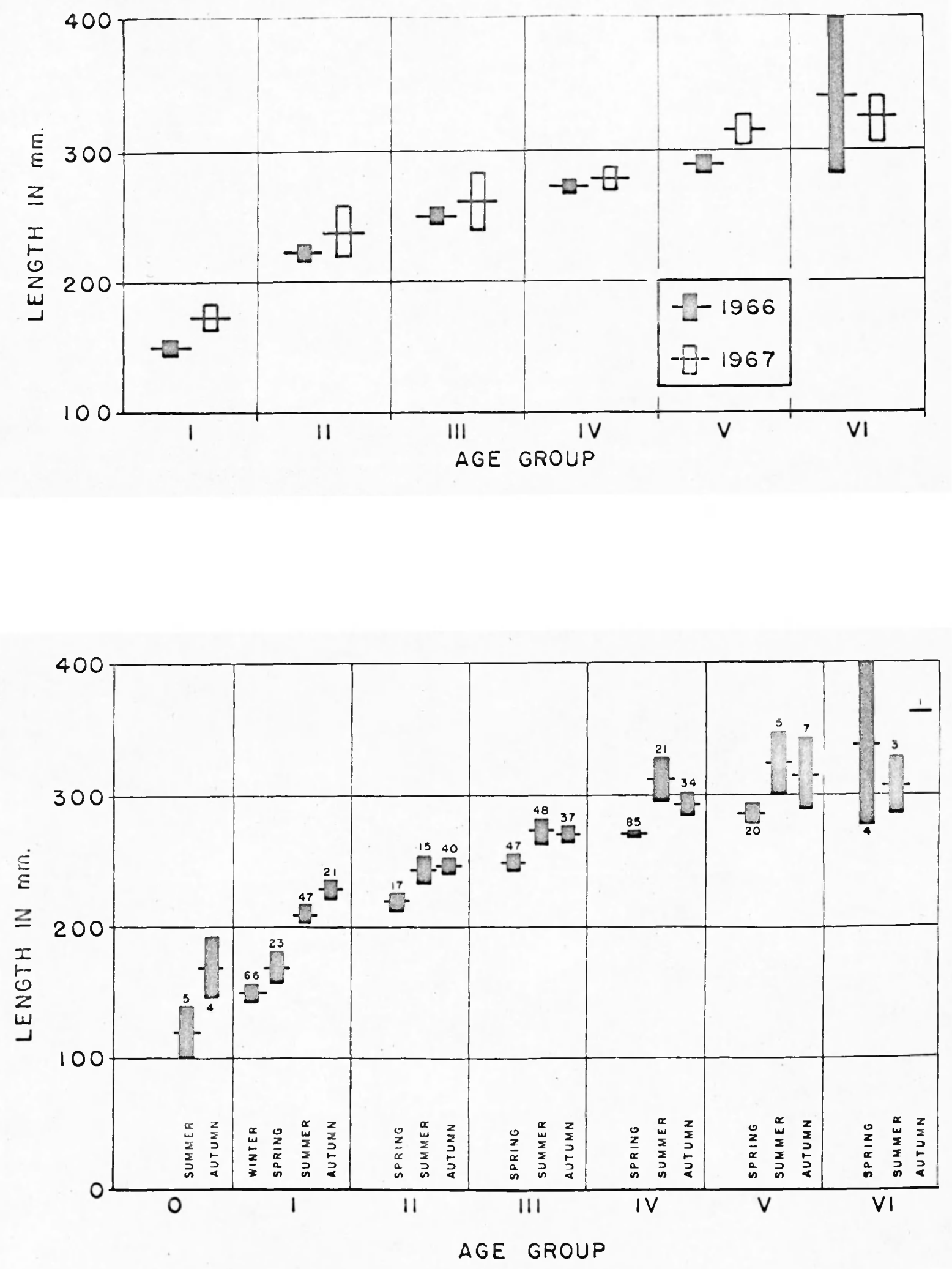
two year olds averaged $151 \mathrm{~mm}$ and $221 \mathrm{~mm}$ and in 1967 they averaged $173 \mathrm{~mm}$ and $237 \mathrm{~mm}$. "Student's" $t$ test (Snedecor, 1956) showed that these mean differences were statistically significant at the $5 \%$ level. The differences were probably due to a change in mesh size of the sampling gear. From 1966 to 1967 the trawl mesh was changed from $1 / 2$ inch to two inches. There was no difference between the mean lengths of the three or four year olds. The three year olds averaged $249 \mathrm{~mm}$ in 1966 and $261 \mathrm{~mm}$ in 1967. The four year olds averaged $272 \mathrm{~mm}$ and $278 \mathrm{~mm}$ in the two years respectively. Age group $V$ averaged $288 \mathrm{~mm}$ in 1966 and $315 \mathrm{~mm}$ in 1967 . The means were significantly different at the $5 \%$ level. The difference was more likely due to sampling than to a difference between the year classes in rate of growth for a given age. The six year olds averaged $341 \mathrm{~mm}$ in 1966 and $323 \mathrm{~mm}$ in 1967. This mean difference was not significant. The largest fish taken was $41.5 \mathrm{~mm}$ and was judged to be seven years old.

Yearly growth of each age group was obtained by subtracting the mean length at the beginning of the growing season from that at the end of the growing season. According to Ricker (1958) the above procedure can be used to estimate yearly growth as long as several criteria are met: (I) there must be no difference between year-classes in respect to rate of growth at any given age; (2) the fish taken must constitute a random sample of each of the age classes involved; (3) and there must be no correlation between size of a fish within an age-group, and mortality rate to which it is subject.

Two of the criteria established by Ricker were met. Each age group had the same growth rate in 1966. as it did in 1967. 
Random samples were obtained by limiting comparisons to samples taken with the same type of trawl and samples in which the particular age groups were well represented. However, data were not sufficient to determine whether on not size of an individual within an age group was an independent variable of mortality rate.

The seasonal and yearly growth is represented in Fig. 5 . During 1966 the yearlings grew about $80 \mathrm{~mm}$. The two year olds averaged $27 \mathrm{~mm}$. The three and four year old fish grew about $22 \mathrm{~mm}$. The five year old fish showed a $30 \mathrm{~mm}$ average increment. Why the mean length of age groups III, IV, and V was greater during the summer than during the following autumn was not apparent. Fish of older age groups were not taken in sufficient quantities to determine yearly growth. Data on growth of young-of-the-year were very sparse because otoliths were obtained from only nine specimens. They averaged $119 \mathrm{~mm}$ in the August-September sample and $169 \mathrm{~mm}$ in the November-December sample.

Striped searobins accomplished more than one-half of their linear growth during their first two years of life. Reduction of linear growth after the second year coincided with sexual maturity. Both sexes became mature during the spring of their third year.

Growth in length occurred during the period when crystalline material was found on the margin of the otolith. As inferred from the otoliths, the yearlings had a longer growing season than the older fish. Yearlings began linear growth in February or March and continued growing until November or December. The growing season of older fish extended from May to November or December. 
Figure 5 further shows that the height of the growing season for all age groups occurred between May and August. The yearlings were the only age group with a significant increase in length between summer and fall.

There was no difference in the growth rate between the sexes. However, chi-square tests showed males predominating at lengths less than $300 \mathrm{~mm}$ and females more numerous at lengths greater than $300 \mathrm{~mm}$. Below $300 \mathrm{~mm} 62 \%$ of the fish were males and above $300 \mathrm{~mm}$ $66 \%$ were females. The change in the sex ratio may have been due to the fact that large females had a slightly lower mortality rate than large males.

Length Frequency Method

The length frequency method has often proved useful in determining the age of fishes. This method is based on the premise that lengths of fish in an age group tend to form a normal distribution (Rounsefell and Everhart, 1953). The lengths of fish of successive age groups form a polymodal curve (Lagler, 1956). The age structure of the population is determined from the number of modes." However, this method is useful for determining the age of younger fish only. Polymodal distribution. in length frequency curves is obscured for larger fish because of reduction of growth rate with time (Van Oosten, 1941).

Lengths of the striped searobin were plotted separately for each sampling period to prevent growth between sampling periods from obscuring the modal distribution. Length frequency comparisons were restricted to fish taken with the same gear. Only fish taken with the semi-balloon trawl were used in 1966 and only fish 
taken with the Atlantic western trawl were used in 1967. The length frequencies for 1966 showed polymodality and seasonal progression of modal size (Fig. 6). The growth of age groups 0 and I could be followed during the year. The winter sample was unimodal and consisted entirely of yearlings. By spring this age group consisted of fish from $118 \mathrm{~mm}$ to $197 \mathrm{~mm}$. Yearlings had a modal length of $220 \mathrm{~mm}$ during summer and $240 \mathrm{~mm}$ during autumn. Age group 0 was first seen in summer and by autumn it ranged from $148 \mathrm{~mm}$ to $187 \mathrm{~mm}$. The length frequency distributions were less helpful for identifying older age groups. Polymodal distribution was clearly evident only in the summer sample. The modes at $250 \mathrm{~mm}, 275 \mathrm{~mm}$, and $300 \mathrm{~mm}$ probably represented age groups II, III, and IV respectively.

Two adequate length frequencies were obtained during 1967 (Fig. 7). The bimodal curves gave an indication of growth and size of the yearlings during the spring. Between the sampling periods in March and May this group showed a modal increase from $165 \mathrm{~mm}$ to $188 \mathrm{~mm}$. The second mode in each of these samples consisted of the older age groups which, because of reduction of growth rate, could not be individually discerned.

The results of the length frequency method supported those of the otolith method. Table 3 shows that the mean length of yearlings determined by the length frequency analysis were very close to those determined by the otolith analysis. Both methods indicated that linear growth was reduced after the first year. After age I the means of successive age groups were separated by less distance; therefore, the age groups could not be differentiated on the histograms in Fig. 6 and Fig. 7. 
Fig. 6

Length frequencies of the striped searobins during each of the seasons of 1966. 


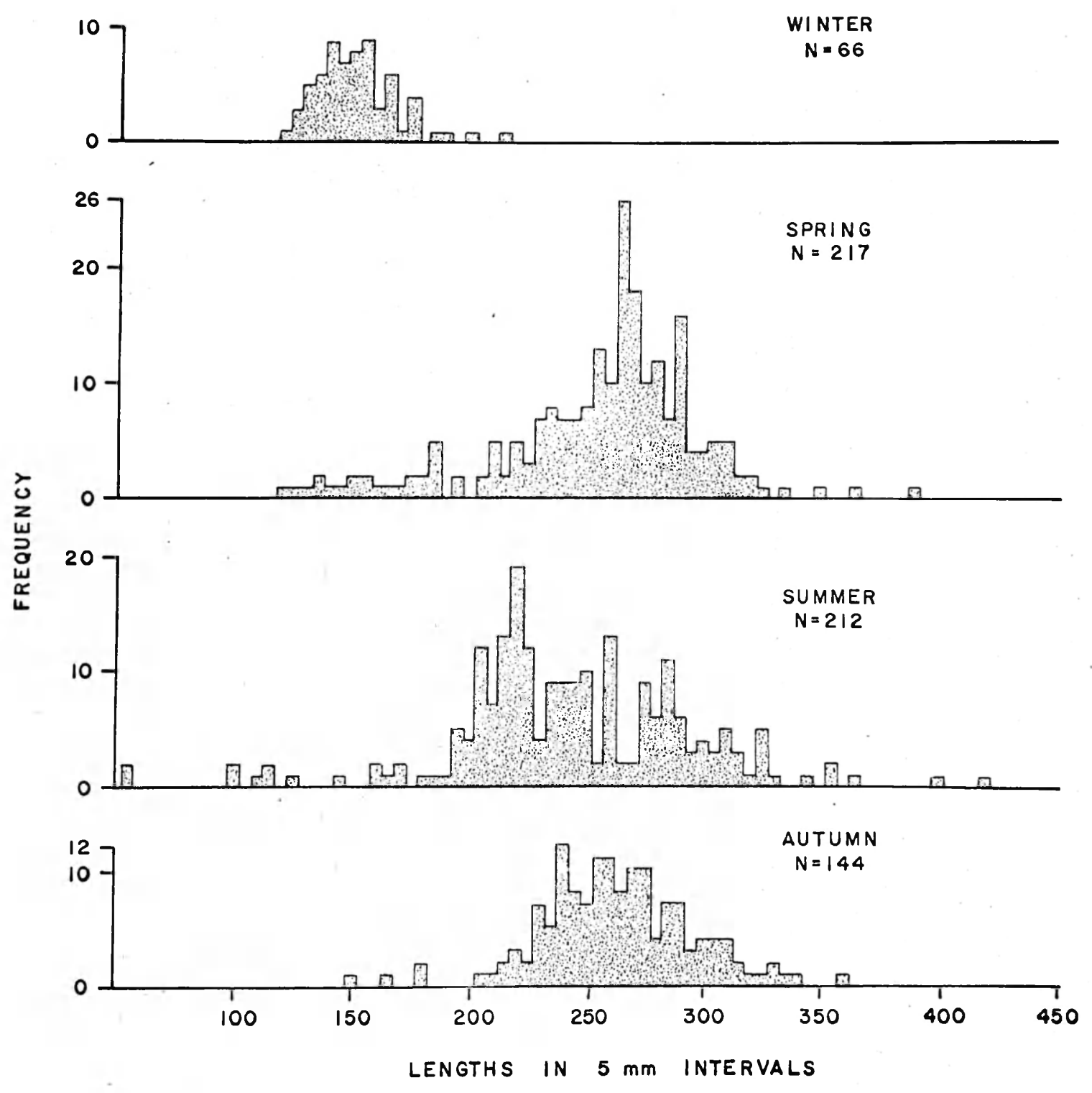




\section{Fig. 7}

Length frequencies of the striped searobins during first three seasons of 1967. 


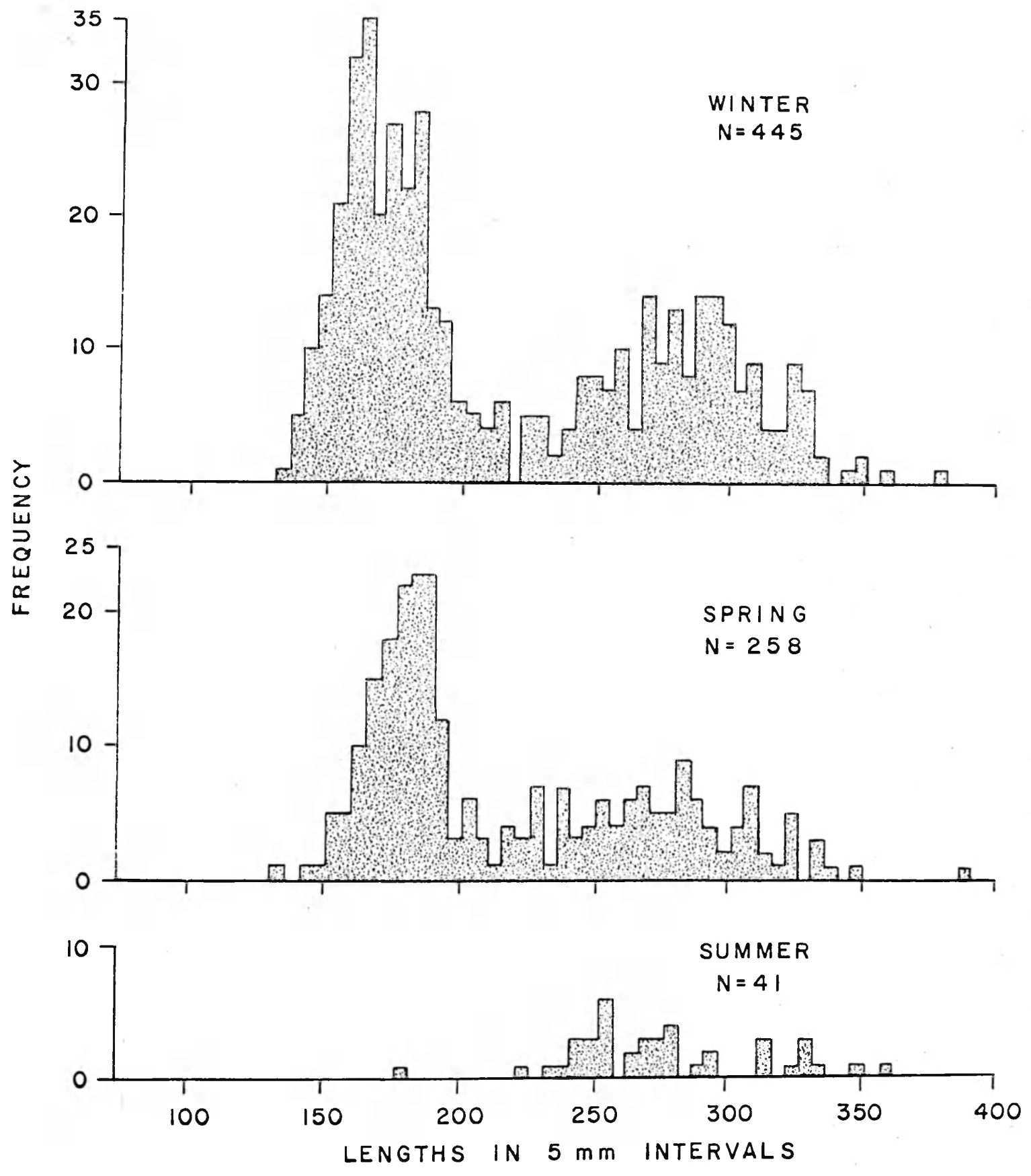




\section{TABLE 3}

MEAN LENGTHS OF YEARLINGS AS DETERMINED BY LENGTH

FREQUENCY METHOD AND BY THE OTOLITH METHOD.

\begin{tabular}{lcccccc}
\hline \hline & & & & & & \\
& $\begin{array}{c}\text { Winter } \\
1966\end{array}$ & $\begin{array}{c}\text { Spring } \\
1966\end{array}$ & $\begin{array}{c}\text { Summer } \\
1966\end{array}$ & $\begin{array}{c}\text { Fall } \\
1967\end{array}$ & $\begin{array}{c}\text { Winter } \\
1967\end{array}$ & $\begin{array}{c}\text { Spring } \\
1967\end{array}$ \\
$\begin{array}{l}\bar{\chi} \text { Length Frequency } \\
\text { method }\end{array}$ & 149 & 155 & 203 & 228 & 171 & 182 \\
$\bar{\chi}$ Otolith method & 151 & 172 & 211 & 230 & 173 & 185 \\
\hline
\end{tabular}


The estimate of growth of age groups 0 and I may have been biased by the capture of only the large members of these age groups. All of the specimens used for age analysis were taken over the continental shelf and these fish were considerably larger than those taken at the same time from the estuaries and inlets (Table 4).

Earlier studies also indicate that the growth of age groups 0 and I was over estimated. Smith (1898) stated that striped searobins reach about 4 inches $(102 \mathrm{~mm}$ ) by their first autumn. Nichols and Breder (1927) obtained young fish averaging 68 mm fork length in August and $86 \mathrm{~mm}$ fork length in October. Warfel and Merriman (1944) collected fish averaging $44 \mathrm{~mm}$ in early August, $57 \mathrm{~mm}$ in late August, one fish $108 \mathrm{~mm}$ in early September, and fish ranging from $66 \mathrm{~mm}$ to $108 \mathrm{~mm}$ in mid-September. A conversion factor (1.23) was used to convert standard length, used in the previous studies, to fork length.

Comparison of this Study with an Earlier Study

Marshall (1946), using scales, found growth of the striped searobin more variable and more rapid than was indicated by analysis based on heated otoliths (Table 5). The spring and summer samples of 1966 were combined in order to compare with Marshall's sample which was collected during most of the summer. Also it was necessary to convert the standard lengths taken by Marshall to fork lengths. Heated otoliths were a better indicator of age than scales. From scales Marshall could determine age for only the first three years and he discarded $44 \%$ of fish longer than $314 \mathrm{~mm}$ because of obscurity of annuli. However, from processed otoliths, age could be determined for the first seven years and only $20 \%$ of the fish longer than $314 \mathrm{~mm}$ were discarded because of irregularities in the otoliths. 


\section{TABLE 4}

NUMBER AND FORK LENGTHS OF STRIPED SEAROBINS OBTAINED

FROM INLETS AND ESTUARIES DURING 1966-67.

\begin{tabular}{|c|c|c|c|c|c|c|}
\hline & May & June & July & August & September & October \\
\hline \multicolumn{7}{|l|}{ Yearlings } \\
\hline Number & 11 & 8 & 1 & 2 & & \\
\hline Length range ${ }^{l}$ & $61-156$ & $154-200$ & 195 & $150-190$ & & \\
\hline Mean length & 115 & 177 & 195 & 170 & & \\
\hline \multicolumn{7}{|c|}{ Young-of-the-year } \\
\hline Number & & & & 3 & 3 & 2 \\
\hline Length range ${ }^{I}$ & & & & $54-73$ & $57-104$ & $57-62$ \\
\hline Mean length & & & & 65 & 87 & 60 \\
\hline
\end{tabular}




\section{TABLE 5}

LENGTHS OF AGE GROUPS O-III OBTAINED BY THE PRESENT STUDY AND THOSE OBTAINED BY MARSHALL'S STUDY

$\begin{array}{lcccc}\text { Age Group } & 0 & \text { I } & \text { II } & \text { III } \\ \text { Fork lengths } & & & & \\ \text { Present study } & <124 & 134-242 & 208-276 & 219-301 \\ \text { Marshall's study }^{I} & <123 & 154-283 & 209-326 & 271-344\end{array}$

${ }^{1}$ lengths in $\mathrm{mm}$ 


\section{DISTRIBUTION}

Striped searobins make an annual onshore-offshore migration, probably in response to changing water temperatures. During the coldest period of the year, February and March, the striped searobins are in warmer offshore water. With onset of vernal warming the fish move inshore and remain there until the coastal waters begin to cool in autumn. In winter, 1966 the fish were dispersed between the 11 and 100 fathom contours. Figure 8 shows that fish were most abundant between 21 and 30 fathoms. In this depth range an average of 5.4 fish were caught per tow. By spring the fish were concentrated in shallow water (Fig. 9). Water shoaler than 11 fathoms yielded an average of 16.8 fish per tow. In summer all of the fish were found in water shoaler than 21 fathoms (Fig. 10). Tows between shore and 10 fathoms averaged 9.1 fish per tow, tows between 11 and 20 fathoms averaged $8.0 \mathrm{fish}$. By autumn the fish had dispersed and were caught between shore and the 40 fathom isobath (Fig. I1).

Because the range of the striped searobin extends a considerable distance to the north and south of Chesapeake Bight and because fish were captured over the entire Bight during all periods, it could not be determined if there was an annual north-south migration.

The presence of smaller young-of-the-year striped searobins in inlets suggests that age group 0 used this area as a nursery ground. However, since large concentrations of young-of-theyear have not been taken this hyptothesis is tentative. 
Fig $: 8$

Distribution of striped searobins in Chesapeake Bight during winter 1966. Distribution of striped searobins according to depth and bottom water temperature during winter, 1966. 


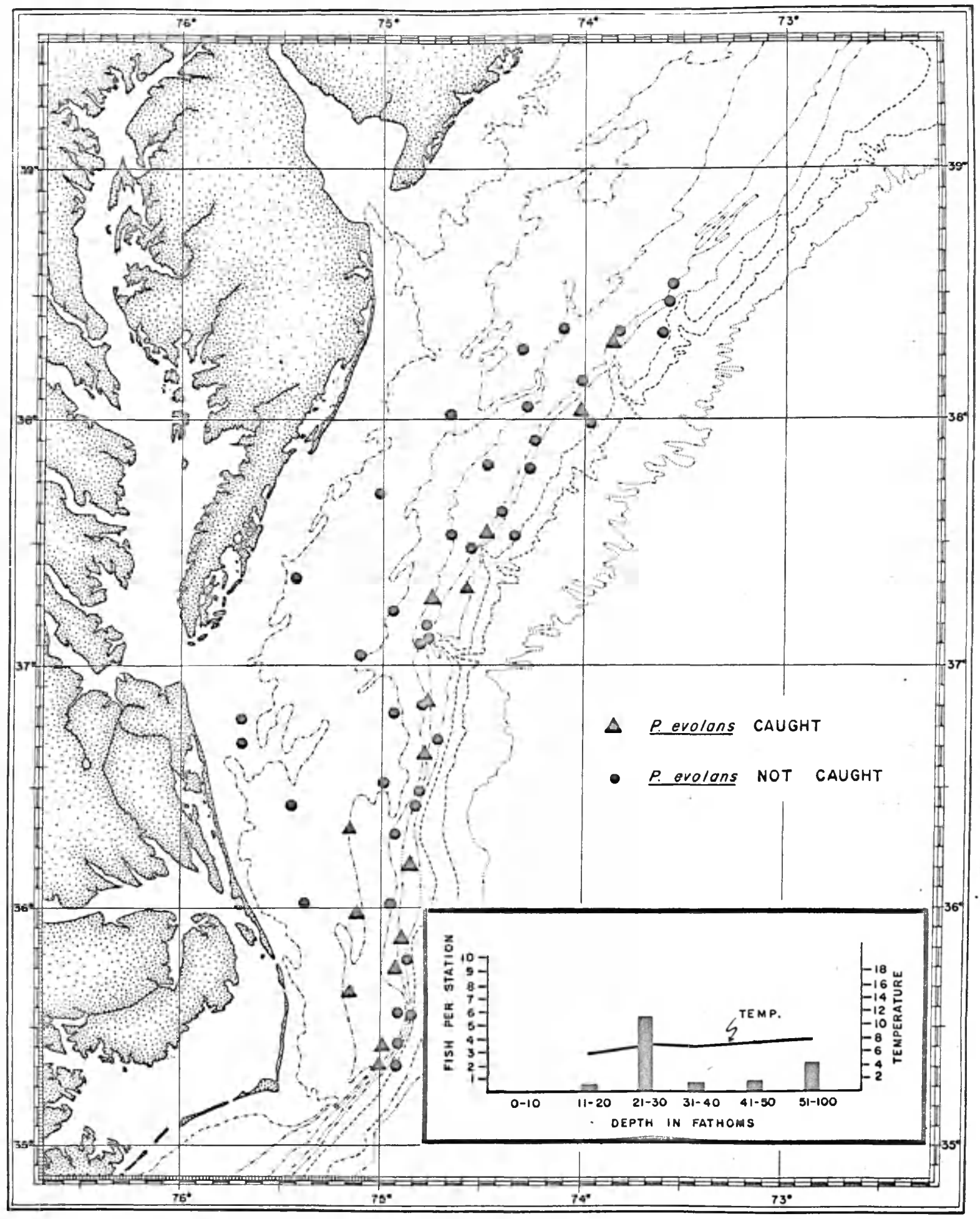


Fig. 9

Distribution of striped searobins in Chesapeake Bight during spring, 1966. Distribution of striped searobins according to depth and bottom water temperature during spring, 1966. 


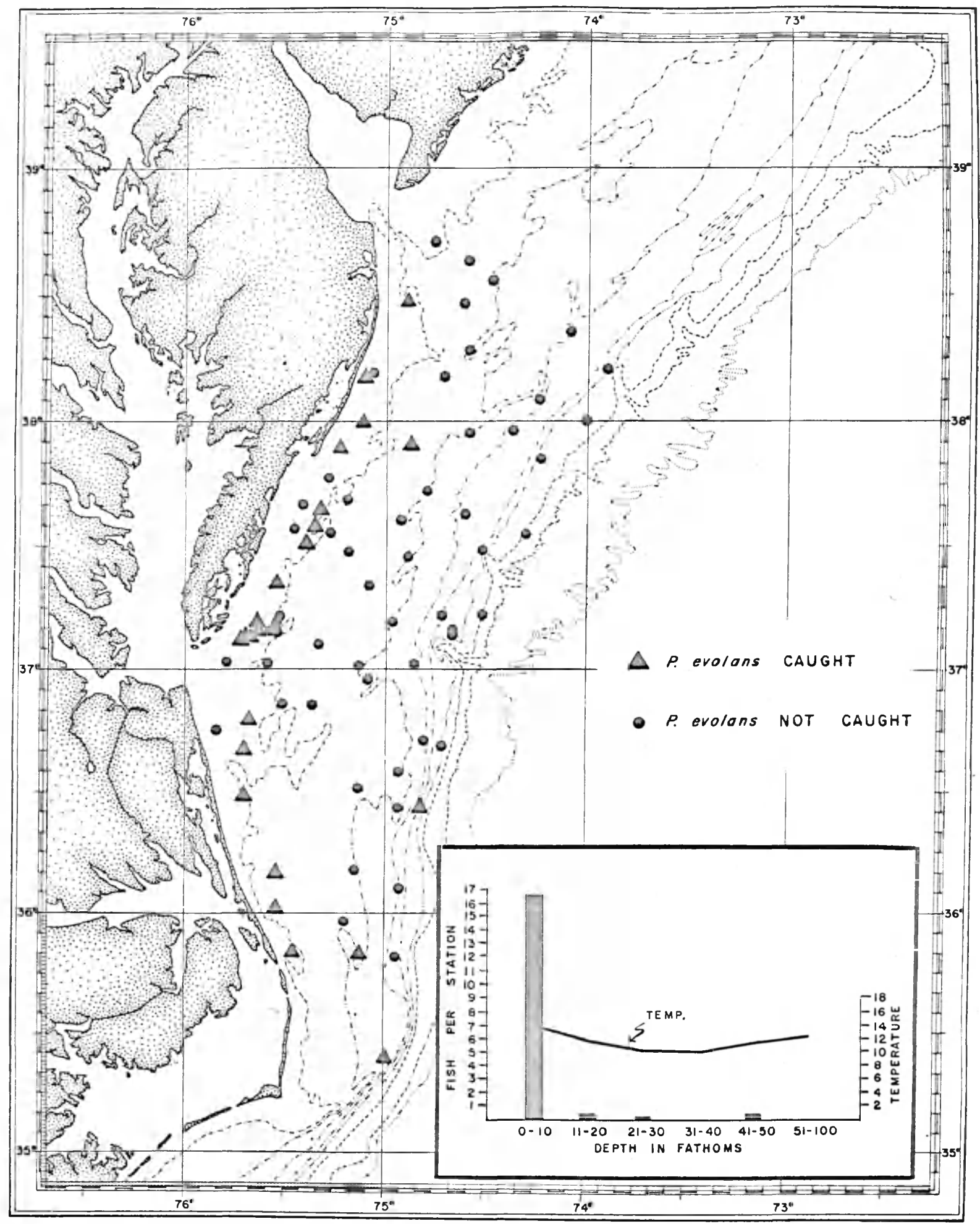


Fig. 10

Distribution of striped searobins in Chesapeake Bight during summer, 1966. Distribution of striped searobins according to depth and bottom water temperature during summer, 1966. 


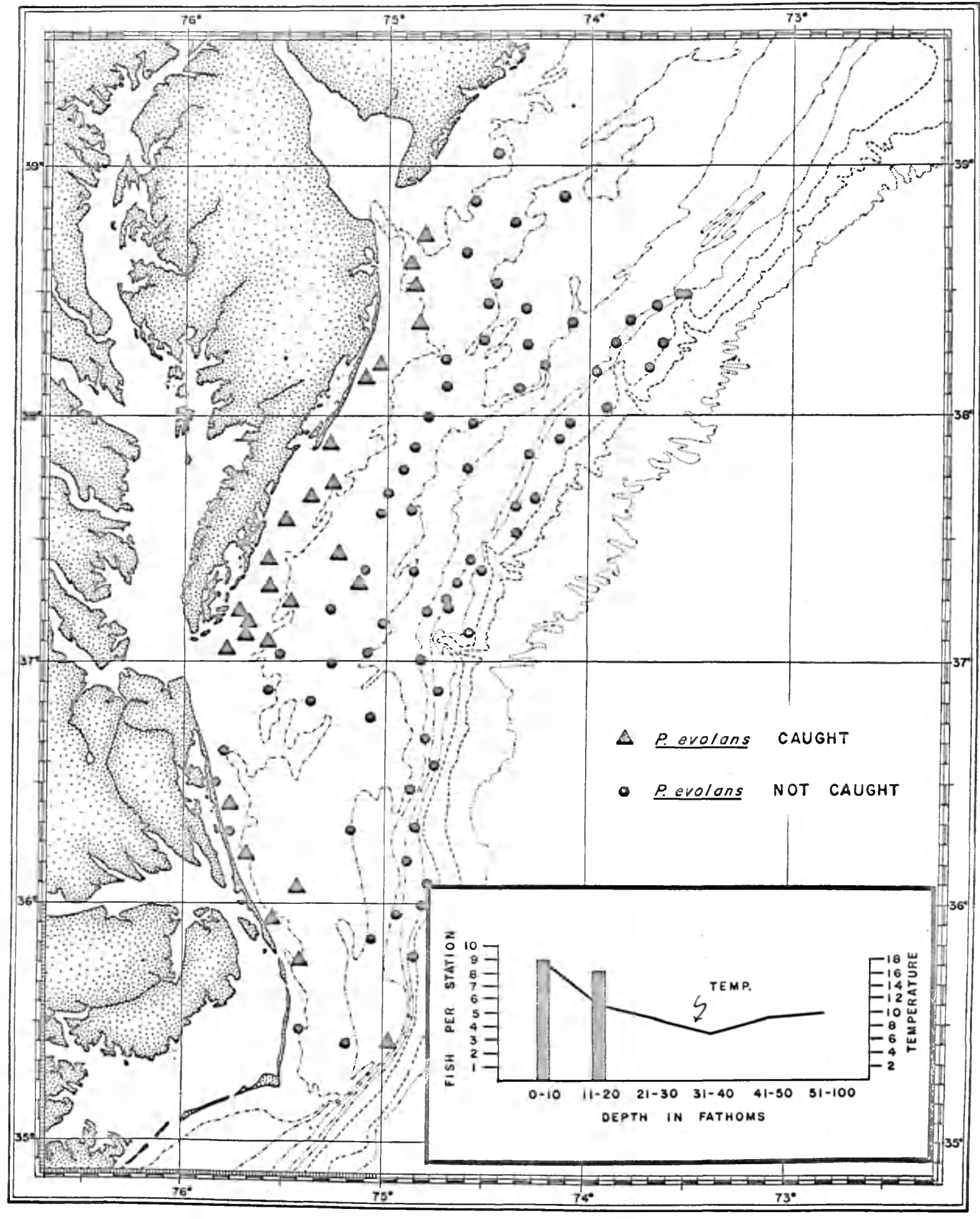




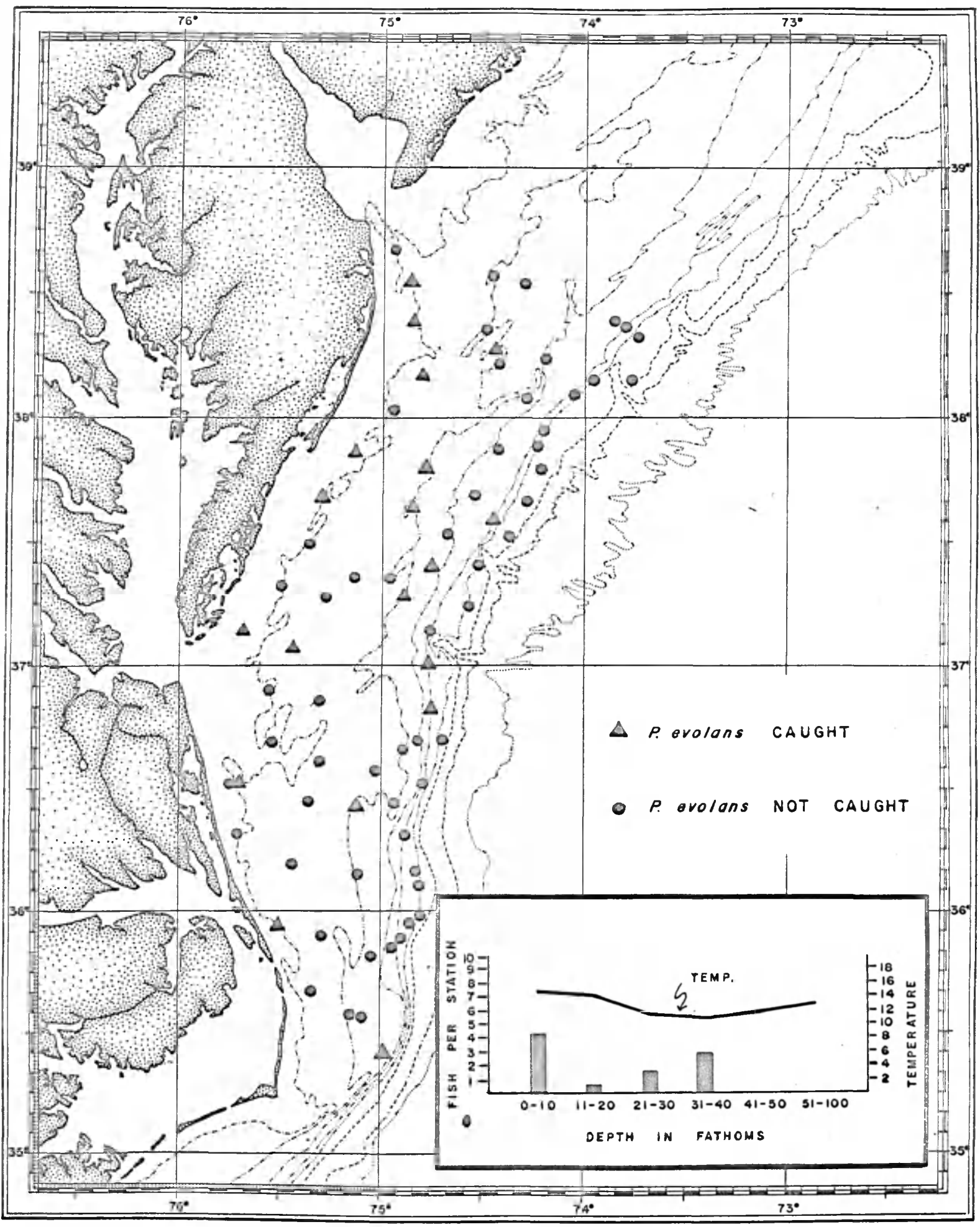


Fig. II

Distribution of striped searobins in Chesapeake Bight during autumn, 1966. Distribution of striped searobins according to depth and bottom water temperature during autumn, 1966. 
GONAD DEVELOPMENT, MATURITY, AND SPAWNING

Maturation of the gonads began during the second spring or summer for both sexes, one year before reaching sexual maturity. Prior to development, the gonads consisted of transparent tubules about $1 \mathrm{~mm}$ in diameter. During development, the tubules increased in size and became opaque; the testes became white and the ovaries yellow-orange. Small eggs were visible under a magnification of 14X shortly after the start of gonadal enlargement. Maturation began in April and by November 100\% of the yearlings showed signs of enlargement of the gonads. Gonadal development was apparently related to size of the fish. Yearlings that underwent early maturation were considerably larger than the mean length for their age group. Yearlings with enlarged gonads in April were longer than $200 \mathrm{~mm}$ and the majority of those which had not begun development by May were less than $185 . \mathrm{mm}$.

All striped searobins were sexually mature by their third spring. During March and April the gonads of fish two years old and older enlarged until they occupied a major portion of the abdominal cavity. Gonads were running ripe from May through July, with the highest incidence of ripe fish occurring in mid-June. Fish were judged to be running ripe if slight pressure on the abdomen extruded milt or transparent eggs. Males and females ripened at about the same time. Fish obtained in August had completed spawning because the gonads were either spent or were recovering from the spent condition. Spent gonads were greatly 
reduced in volume. The recovering gonads were also reduced in volume but immature sex products occupied the anterior section of the gonads. Segments of the striped searobin population had slightly different spawning times. The eștuarine samples obtained during April, 1966 and May, 1967 had a higher incidence of gravid and ripe fish than did the samples taken from continental shelf at the same time.

According to previous authors striped searobins from the northern part of the range also spawned during the spring and summer. Perlmutter (1939) obtained pelagic eggs, thought to be those of striped searobins, from May to July off Long Island. Wheatland (1956) collected eggs of this species in Long Island Sound during May and July. Sumner, et al. (1913) stated that in the southern New England region development of the gonads began in May and spawning occurred during the summer. Marshall (1946) found spawning extending from June to early August in New England waters.

Marshall also reported that yearlings, about $223 \mathrm{~mm}$ fork length, produced ripe eggs. However, $223 \mathrm{~mm}$ is closer to the mean length of age group II than to that of age group I in this study. Age group II averaged $221 \mathrm{~mm}$ prior to spawning while age group I averaged $172 \mathrm{~mm}$. Thus it is likely that the mature fish were age two rather than one year old. 


\section{WEIGHT/LENGTH .RELATIONSHIP}

Linear plots of weights on lengths revealed that weight increased exponentially with length, fitting the formula: $\log W=\log a+b \log L . \quad \log$ plots revealed no difference between the sexes in the weight/length relationship. Covariance tests (Mottley, 1941) were run to determine if the relationship changed significantly during the year (Table 6). The results indicated that all data taken prior to and during spawning could be pooled into one regression and all data taken after spawning could be pooled into a second regression. The former regression, representing 1095 fish, was: $\log W=-5.3371+3.1941 \log L$ and had a correlation coefficient of 0.9943 . The latter regression, representing $288 \mathrm{fish}$, was: $\log W=-4.175+2.72 \log \mathrm{L}$ and had correlation coefficient of 0.9768 . 
TABLE 6 .

RESULTS OF COVARIANCE TESTS RUN BETWEEN SEASONAL

SAMPLES.

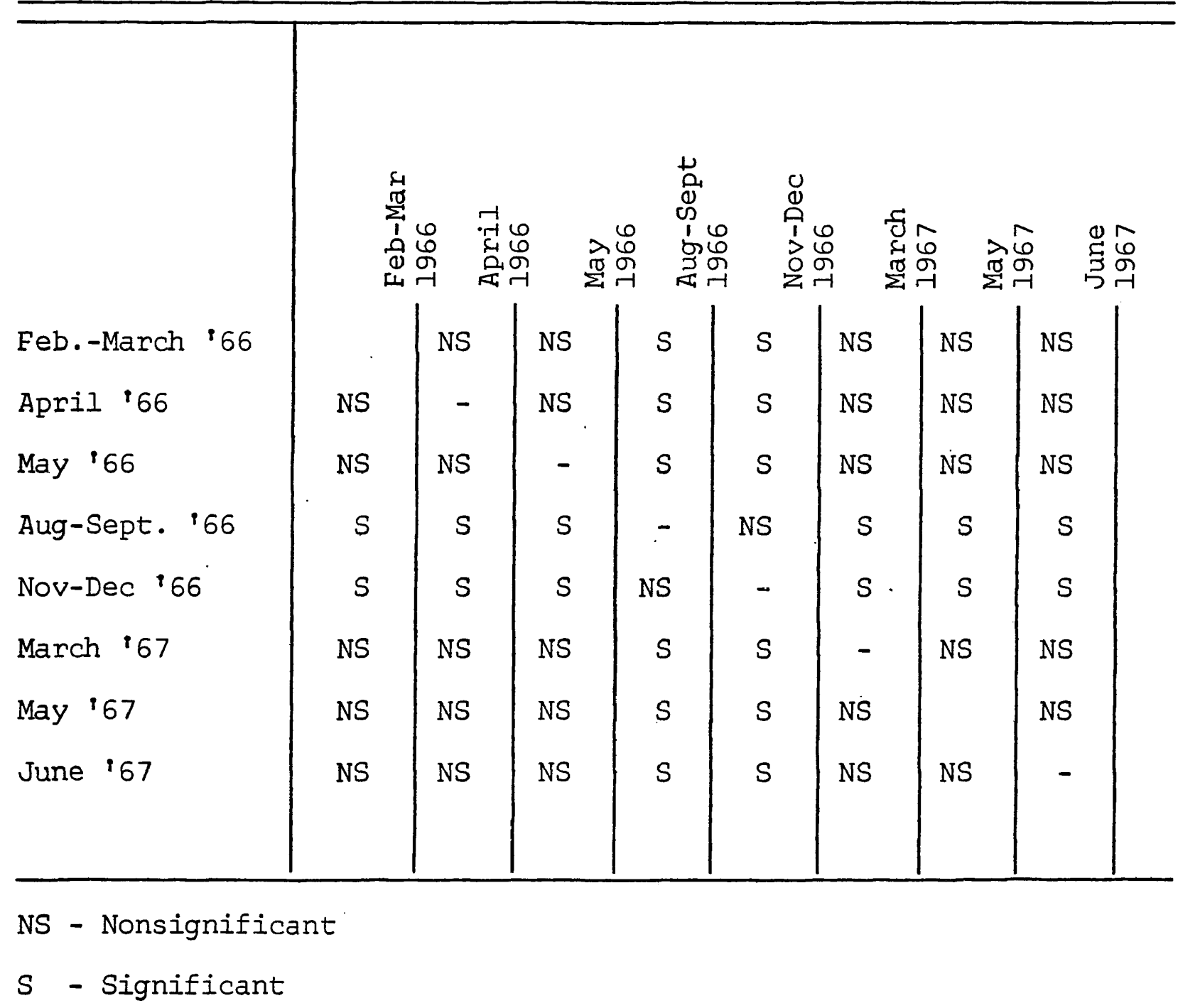


Figure 12 shows that the slope of the regression for fish in the pre spawning and spawning condition was much steeper than that for fish in the post spawning condition. Fish were significantly more robust before completion of spawning than after spawning. The condition of the gonads thus had an important effect on the weight/length relationship. 


\section{RELATIVE CONDITION}

The coefficient of condition, based on the generalization that weight of a fish is a function on the cube of the length, $K=1000 \mathrm{~W} / \mathrm{L}^{3}$ (Hile, 1936), failed to demonstrate the change in the weight/length relationship exhibited by the regressions (Fig. 12). $K$ was computed for each age group during each of the sampling periods. $K$ for each of the age groups increased during the year. Apparently the increase in length during the year masked the change in robustness resulting from the condition of the gonads. To illustrate the effect of spawning, the relative condition factor derived by Le Cren (1951) was used. Relative condition $\left(K_{n}\right)$ is based on the relationship of the observed weight of a particular length group $(W)$ to the weight predicted from the weight/length regression for the length $\operatorname{group} \cdot(\hat{W})$ so that $k_{n}=$ $w / \hat{w}$. The relative condition factor demonstrates all changes in condition not dependent on length.

Relative condition was computed for fish in pre spawning and spawning condition. This group was chosen because it represented the greater number of $\mathrm{fish}$ and the greater time interval. The fish were divided into classes of $10 \mathrm{~mm}$ fork length and relative condition was computed for each class (Fig. 13). The observed weight of each length class was obtained from the average weight of the fish within the $10 \mathrm{~mm}$ increment. The average length in the $10 \mathrm{~mm}$ increment was used to calculate the predicted weight. 
Fig. 12

Weight/length relationship for striped searobins in pre spawning condition and in post spawning condition. 


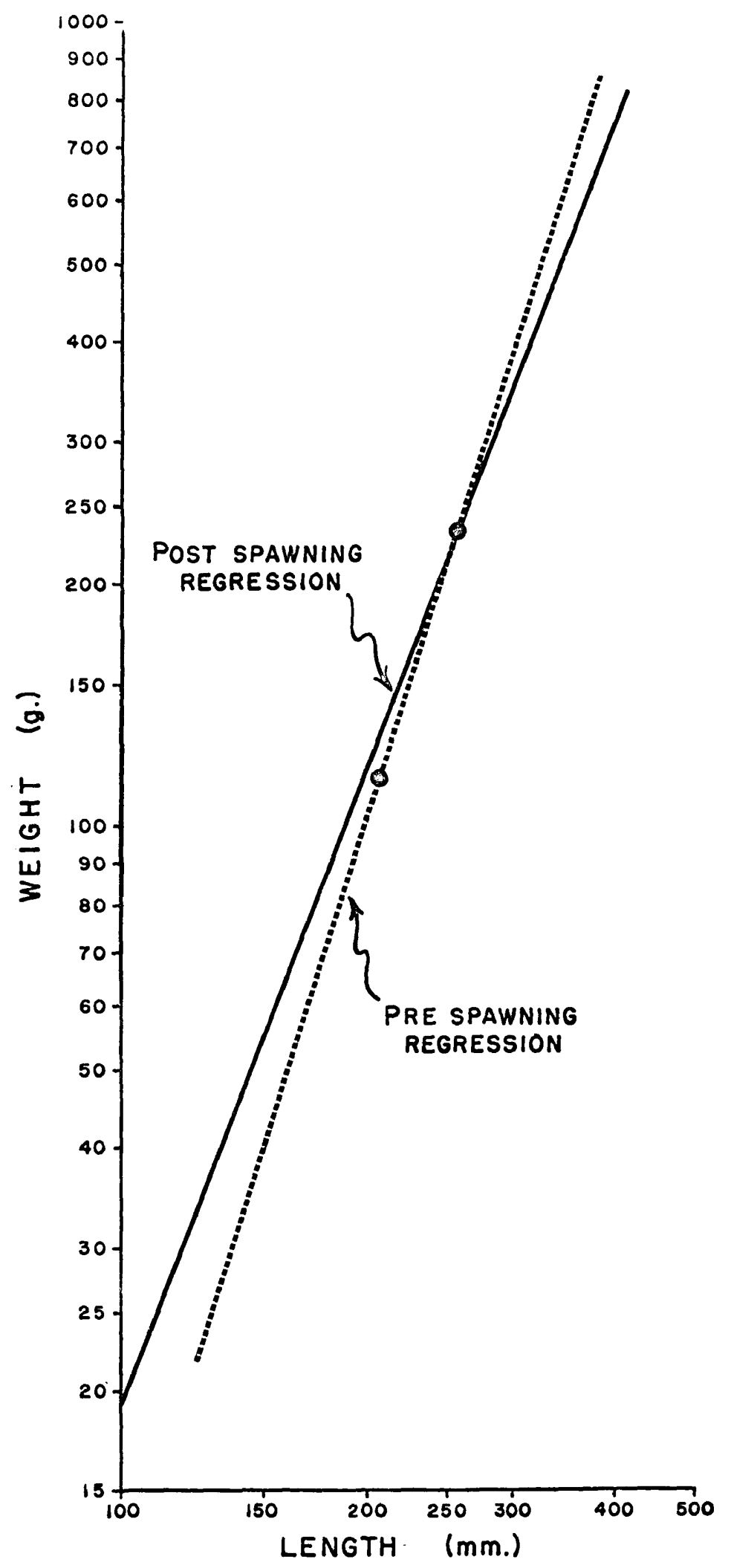


$K_{n}$ declined sharply between $125 \mathrm{~mm}$ and $194 \mathrm{~mm}$ and then climbed to a value slightly above unity at $214 \mathrm{~mm}$. After $214 \mathrm{~mm}$, fluctuations were slight. Two peaks were formed at $254 \mathrm{~mm}$ and $294 \mathrm{~mm}$. Evidently the fish grew disproportionally more in length than in weight between $125 \mathrm{~mm}$ and $194 \mathrm{~mm}$. The increase in robustness between $194 \mathrm{~mm}$ and $214 \mathrm{~mm}$ may be attributed to gonadal development. The peak between $214 \mathrm{~mm}$ and $225 \mathrm{~mm}$ corresponded to the mean length of age group II prior to spawning. The second and third peaks coincided with the mean lengths of age groups III and $V$ prior to spawning. Age group IV was only vaguely indicated by a change in the slope between $264 \mathrm{~mm}$ and $284 \mathrm{~mm}$. The above relationship of high $k_{n}$ values with gonadal buildup lends support to Pantulu's (1963) statement that the number of 'peaks' and 'valleys' in the relative condition curve may be an index of the number of spawnings during the life of the fish. Thus relative condition may be an indicator of the length of a fish at sexual maturity and length at each succeeding age. 
Fig. 13

Relative condition ( $K n$ ) for striped searobins

in pre spawning condition. 


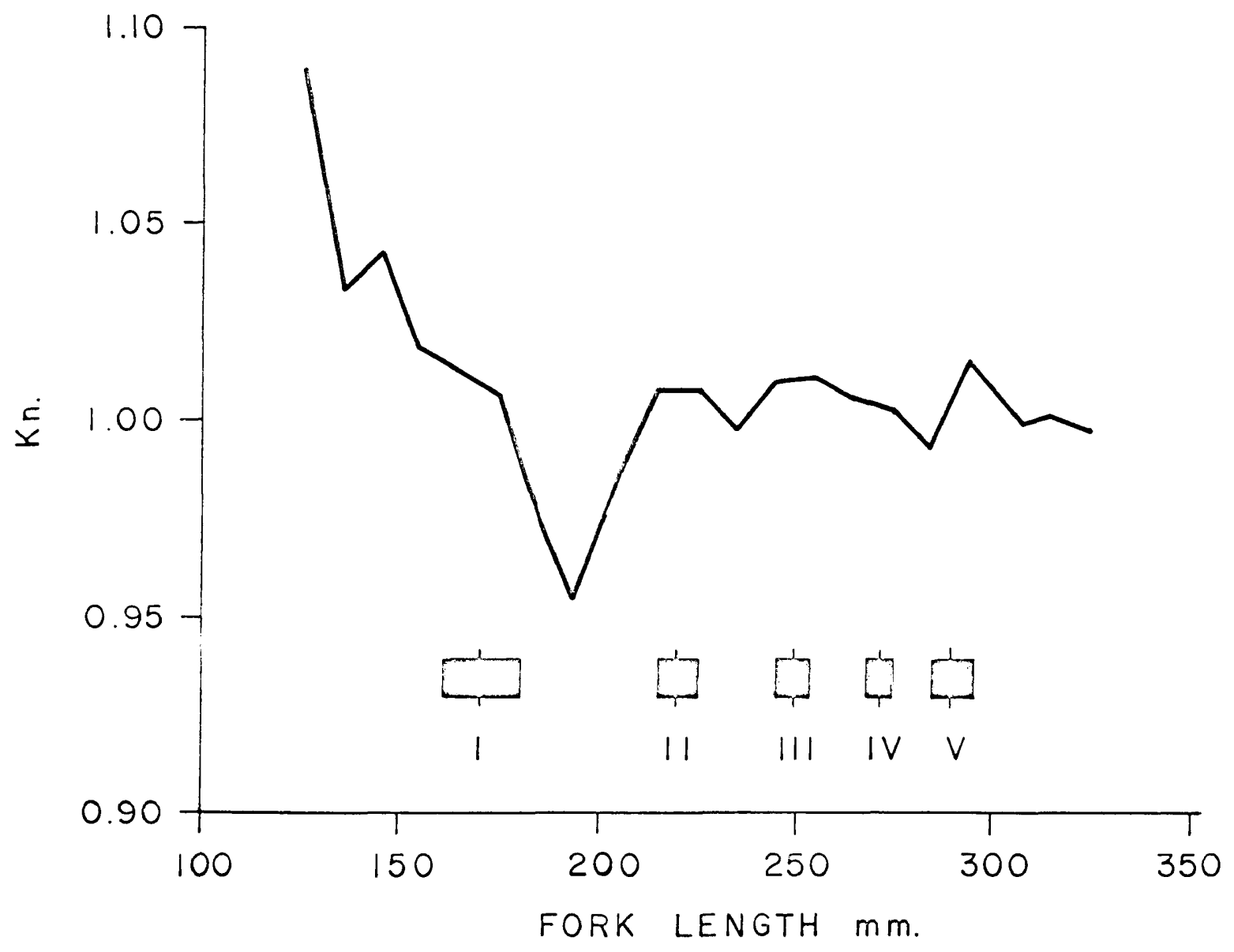




\section{LITERATURE CITED}

Bigelow, H. B. and W. C. Schroeder. 1953. Fishes of the Gulf of Maine. U. S. Fish and Wildlife Serv., Fish. Bull., 74. Vol. $53: 1-577$.

Bratberg, Erling. 1956. On the interpretation of the opaque and hyaline zones in the otoliths of immature redfish (Sebastes marinus L.). J. Cons. int. Explor. Mer, 22(I):66-74.

Bullis, H. R. and J. R. Thompson. 1965. Collections by the exploratory fishing vessels Oregon, Silver Bay, Combat, and Pelican made during 1956-1960 in the southwestern North Atlantic. U. S. Fish and Wildlife Serv., Spec. Sci. Report, Fish., No. 510:1-130.

Christensen, J. M. 1964. Burning of otoliths, a technique for age determination of soles and other fish. J. Cons. int. Explor. Mer, 29(1):73-81.

Chugunova, N. I. 1963. Age and growth studies in fish. Publ. Israel Program Sci. Transl., Jerusalem. 132 pp.

Creaser, C. W. 1926. The structure and growth of the scales of fishes in relation to the interpretation for their life history, with special reference to the sunfish, Eupomotis gibbosus. Misc. Publ. Mus. Zool. Univ. Mich. 17:1-82.

Dannevig, Alf. 1956. The influence of temperature on the formation of zones in scales and otoliths of young cod. Rep. Norw. Fish. Mar. Invest. XI(7):1-16.

Dannevig, E. H. 1956. Chemical. composition of the zones in cod otoliths. J. Cons. int. Explor. Mer, 21(2):156-159.

Fish, Marie P. 1954. The character and significance of sound production among fishes of the western North Atlantic. Bull. Bingham Ocean. Coll., 14(3):83-85.

GambelI, R. and J. Messtorff. 1964. Age determination in the whiting Merlangius merlangus L. J. Cons. int. Explor. Mer, $28(3): 393-404$.

Ginsburg, I. 1950. Review of the western Atlantic Triglidae (Fishes). Texas Jour. Sci., no. 4:489-527.

Hickling, C. F. 1931. The structure of the otolith of the hake. Quart. J. Microscopical Sci. 74:547-562. 
Hildebrand, S. F. and W. C. Schroeder. 1928. Fishes of Chesipeake Bay. U. S. Bur. Fish., Bull., 43 (l):1-366.

Hile, Ralph. 1936. Age and growth of the cisco, Leucichthys artedi (Le Sueur), in the lakes of the northeastern highlands, Wisconsin. U. S. Bur. Fish. Bull. 48: 21l-317.

Irie, Takaaki. 1955. The crystal texture of the otolith of a marine teleost Pseudosciaena. J. Fac. Fish. Anim. Husb. Hiroshima Un. Fukuyama l(1):1-8.

- 1957. On the forming of annual rings in the otoliths of several teleosts. J. Fac. Fish. Anim. Husb. Hiroshima un. Fukuyama 1 (3): 311-317.

- 1960. The growth of the fish otolith. J. Fac. Fish. Anim. Husb., Hiroshima Un. Fukuyama 3 (1):203-221.

Jordan, D. S. and B. W. Evermann. 1898. The fishes of North and Middle America. Bull. U. S. Nat. Mus., 47(2):1241-2183.

Jordan, D. S. and E. G. Hughes. 1887. A review of the American species of the genus Prionotus. Proc. U. S. Nat. Mus., 1886, $9: 327-338$.

Lagler, K. F. 1956. Freshwater fishery biology. Wm. C. Brown Co., Dubuque, Iowa. $421 \mathrm{p}$.

Lawler, G. H. and G. P. McRae. 1961. A method for preparing glycerin-stored otoliths for age determination. J. Fish. Res. Bd. Canada 18(1):47-50.

Le Cren, E. D. 1951. The length-weight relationship and seasonal cycle in gonad weight and condition in perch (Perca fluviatilis). J. Anim. Ecol. 20:201-19.

Leim, A. H. and L. R. Day. 1959. Records of uncommon and unusual fishes from Eastern Canadian waters, 1950-1958. J. Fish. Res. Bd. of Canada 16 (4):503-514.

Marshall, Nelson. 1946. Observations on the comparative ecology and life history of two searobins, Prionotus carolinus and Prionotus evolans strigatus. Copeia, (3):118-i44.

Mottley, C. McC. 1941. The covariance method of comparing the head-lengths of trout from different environments. Copeia, (3):154-159.

Moulton, J. M. 1958. Influencing the calling of searobins, Prionotus spp., with sound. Biol. Bull., Woods Hole 111 1956: 393-398.

Nichols, J. T. and C. M. Breder, Jr. . 1927. The marine fishes of. New York and southern New England. Zoologica, 9 (1):1-192. 
Nikolsky, G. V. 1963. The ecology of fishes. Academic Press, London and New York. 352 p.

Pantulu, V. Rayappa. 1963. Studies on the age and growth, fecundity and spawning of Osteogeneiosus militaris (Linn.) J. Cons. int. Explor. Mer, 28(2):296-315.

Perlmutter, A. 1939. An ecological survey of young fish and eggs identified from tow-net collections. Section I. A biological survey of the salt waters of Long Island, 1938. Part II. Suppl. 28 Ann. Rept., New York State Conserv. Dept., Albany, no. 15 , pt. 2 sect. 1 , pp 11-71.

Poinsard, F. and J. P. Troadec. 1966. Determination de l'age par la lecture des otolithes chez deux especes de Sciaenides Ouest-Africains (Pseudotolithus senegalensis C. V. et Pseudotolithus typus Blkr.). J. Cons. int. Explor. Mer, 30(3):291-307.

Ricker, W. E. 1958. Handbook of computations for biological statistics of fish populations. Bull. Fish Res. Bd.

Canada. No. 119:1-300.

Rounsefell, G. A. and W. H. Everhart. 1953. In: Fishery Science, Its Methods and Applications. 297-327. Publ. John Wiley and Sons Inc. $444 \mathrm{p}$.

Smith, H. M. 1898. Fishes found in the vicinity of Woods Hole. U. S. Fish. Comm., Bull. 17:85-11l.

Snedecor, G. W. 1956. Statistical Methods. Publ. Iowa State U. Press, Ames, Iowa. 534 p.

Sumner, F. B., R. C. Osburn, and L. J. Cole. 1913. A biological survey of the waters of Woods Hole and vicinity. Part II, Section III - A catalogue of the marine fauna. U. S. Bur. Fish., Bull., 31:549-794.

Taylor, Harden F. 1914. The structure and growth of the scales of the squeteague and the pigfish as indicative of their life-history. U. S. Bur. Fish. Bull. 34:287-330.

Tester; Albert I. 1932. Rate of growth of the small mouthed black bass (Micropterus dolomieui) in some ontario waters. Publ. Ontario Fish. Res. Lab. 47:205-221.

Van Oosten, John. 1923. The whitefishes (Coregonus clupeaformis). A study of the scales of whitefishes of known ages. Zoologica $2(17): 380-412$.

- 1929. Life history of the lake herring (Leucichthys artedi LeSueur) of Lake Huron as revealed by its scales, with a critique of the scale method. U. S. Bur. Fish. Bull.; $44: 265-428$. 
Van Oosten, John. 1941. The age and growth of fresh-water fishes. In: A Symposium on Hydrobiology. p. 196-206. Univ. Wisc. Press.

Warfel, H. E. and D. Merriman. 1944. Studies on the marine resources of southern New England. I. An analysis of the fish population of the shore zone. Bull. Bingham Ocean. Coll., $9(2): 1-91$.

Wheatland, Sarah B. 1956. Oceanography of Long Island Sound. 1952-1954 VII. Pelagic fish eggs and larvae. Bull. Bingham Ocean. Coll., 15(7):234-314. 